\title{
ARS-GIS based Spatial Analysis and Assessment on the Urban Growth of Delhi National Capital Territory (NCT) from 1977 to 2014
}

\author{
Rabin Das¹ (dasrabin0@gmail.com) \& Goutam Das² (goutamrs2012@gmail.com) \\ ${ }^{1}$ Assistant Professor, Dept. of Geography and Environment Management, Bajkul Milani Mahavidyalaya, \\ Purba Medinipur, West Bengal, India \\ ${ }^{2}$ Cartographer \& Research Fellow, PG Dept. of Geography \& Environment Management, Bajkul Milani \\ Mahavidyalaya, Purba Medinipur, West Bengal, India
}

\begin{abstract}
:
Introduction: Rapid urbanization and urban growth, particularly in the developing worlds, is continuing to be one of the crucial issues of global change in affecting the physical dimensions of cities.

[d Case description with Methodology: This study proposes a technique to extract urban built-up land features from, Multi Spectral Scanner System (MSS-1977), Landsat Thematic Mapper (1998, 2003, and 2014) and Hyperion EO-1imagery of part of Delhi NCT in India as examples. The study selected two indices, Normalized Difference Built-up Index (NDBI), Normalized and Normalized Different Vegetation Index $(\boldsymbol{N D V I})$ to represent three major urban land-use classes, built-up land and vegetation, respectively. The relationship between land use/land cover (LU/ LC) change and population shift and their effects on the spatiotemporal patterns of urban area were quantitatively examined using an integrated approach of remote sensing, geographical information systems (GIS). Consequently, the seven bands of an original Landsat image were reduced into three thematic-oriented bands derived from above indices. The three new bands were then combined to compose a new image. As a result, the spectral signatures of the three urban land-use classes are more distinguishable in the new composite image than in the original seven-band image as the spectral clusters of the classes are well separated. Therefore, the technique is effective and reliable. In addition, the advantages of over NDVI and over NDBI in the urban study are also discussed in this paper. Furthermore, in combination with the detection of LU/ LC change, an analysis of the spatially differential growth rates for developed land area and population size revealed an urban e sub-urban gradient pattern of population shifting, as evidenced by a sharp increase in developed land area within the middle sub-zones at the urban fringe and the exurban sub-zones beyond the outer traffic ring. As the result, changes in LU/ LC and population shifts resulted in significant variation in the spatiotemporal patterns of the urban area due to the loss of water bodies and vegetated surfaces.

Discussion and Evaluation: Results indicate that the built-up area in the study area has increased by 290\%; from $165.52 \mathrm{~km}^{2}$ in 1977 to $645.3799 \mathrm{~km}^{2}$ in 2014 . The results of the multi-temporal change detection show that the highest urban growth rates, $216 \%$ occurred between 2003 and 2014. In contrast, the growth rates were 10\% during $1977-1998$ and $12 \%$ during the period $1998-2003$. This massive growth was mainly resulted from the transformation of agricultural and barren land of the outskirt of core city. Peri-urban areas are often characterized by valuable natural environment and resource bases to provide essential ecosystem functions for urban residents. Observing land cover change over time can reveal the effects and impacts of urbanization in peri-urban areas. Existing built-up areas have a greater influence on urban expansion outside urban planned districts than in urban planned districts.

Conclusion: It is suggested that a guiding plan is required to integrate planning in both urban and non-urban planned districts to overcome urban sprawl in peri-urban areas and to maintain the sustainable and balanced urban growth here.
\end{abstract}

Keywords: Rapid urbanization and urban growth, Delhi NCT, NDVI, NDBI, urban land-use, Peri-urban areas, urban sprawl and sustainable and balanced urban growth.

\section{INTRODUCTION}

Population growth is a major problem in much urban country like China, India, and Africa etc. Rapid Urbanization causes disorganized and unplanned growth of town and cities. Urbanization has been a universal and important social and economic phenomenon taking place all around the world. Urbanization could be the most powerful and visible anthropogenic force that has brought about fundamental changes in land cover and landscape pattern around the globe. Urbanization and urban growth, especially in the developing world, is 
continuing to be one of the crucial issues of global change. Thrpugh the tremendous process of recent population explosion, most of the developing and under developing countries are deeple affected by uncontrolled population growth which has compelled the civilized man to do the uncivilized, illegal, haphazard and unscientific activities for fulfilling the explosing demends of increasing anthroposphere. India may one typical example of it where greeds rather than needs show the blusterous trend towards unplanned urbanization with huge unethical, undeliberate, shortsighted and eco-blind anthropogenic activities. Delhi NCT reflects also such type of scenario with its overwhelming urbanization and detonating population like the metropoliton behaviour in any advanced developing country. Here lies the essence of this study as the spatio-temporal change analysis and assessment of the urban growth over Delhi NCT during the period, 1977-2014.

\section{AIM OF THE STUDY:}

The present study aims to identify the spatio-temporal changes occurring over Delhi National Capital Territory region using long term satellite data.

\section{Objective of the study:}

1. To estimate areas under different landuse and land cover classes using supervised image classification technique.

2. To identify the spatio-temporal changes through change detection technique and detect the pace and direction of urban growth using long term satellite data.

3. Mapping the socio-economic changes of the study area and analyzing the causes of such rapid urban growth in Delhi.

\section{THE STUDY AREA}

Delhi is the capital of India. The state is spread over an area of 1473 square kilometer. According to the Indian geography the state is located at the center of the Indian subcontinent, amidst the ranges of Himalaya and the Ravalli.

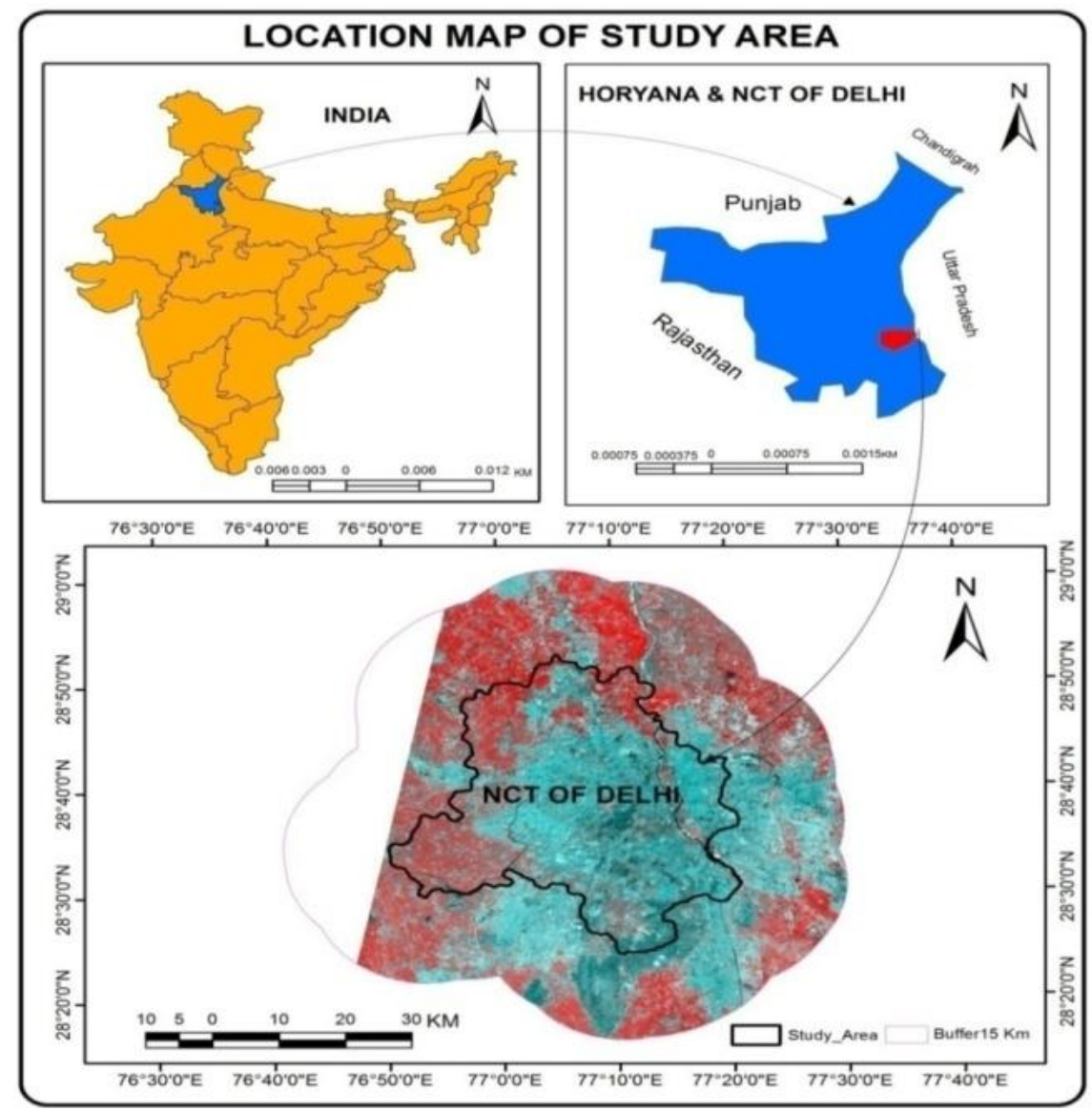

Figure-1: Location Map of the Study Area

The study area is located Centre of the Delhi in India. The study area is bounded by Latitude $28024^{\prime} 16.84^{\prime \prime} \mathrm{N}$ to $28052^{\prime} 52.31^{\prime \prime} \mathrm{N}$ and Longitude $7705^{\prime} 12.02^{\prime \prime} \mathrm{E}$ to $77010^{\prime} 9.83^{\prime \prime} \mathrm{E}$. The total boundary of the study area is $1473.1677 \mathrm{sq} . \mathrm{km}$. 


\section{TOPOGRAPHY}

The entire topography of Delhi is divided into a ridge, the Yamuna Flood Plain, the Plain. It is interesting to note here that each of these regions is marked by distinct type of vegetation. The ridge area of the city offers the right factors that favor the growth of acacias and other cacti. However, during the monsoon, herbaceous plants grow in abundance in the ridge. As far as the plain region of Delhi is concerned, it is characterized by shisham trees.

\section{DRAINAGE}

Drainage pattern of an area is very important in terms of its groundwater potentiality. It is the source of surface water and is affected by structural, lithological and geomorphological control of an area (Schumm, 1956). This may be due to more or less homogeneous lithology and structural controls. Yamuna River is the main control of drainage system along the NCT of Delhi. Reverie type of vegetation grows along the plain of Yamuna. National Capital Region in general, is a part of well integrated drainage system of the Ganga basin. Drainage is an important element of physical infrastructure and constitutes removal and disposal of surplus rain/irrigation water from the land.

\section{VEGETATION}

Vegetation cover in this area has been found to be predominantly--- According to report of 1977 total vegetation cover is $367.425 \mathrm{sq}$. $\mathrm{Km}$. 1998 total vegetation cover is $279.3114 \mathrm{sq} . \mathrm{Km} .2003$ total vegetation cover is 404.3061 sq. Km. 2014 total vegetation cover is 71.5851.Km. The Vegetation of Delhi varies with its varied topography and comprises small and medium sized plants and shrubs.

\section{CLIMATE}

Delhi Weather varies with the different climatic conditions that are faced by this city. Summer weather condition of Delhi is characterized by scorching heat and unbearable temperature. Temperature reaches almost $45^{\circ} \mathrm{C}$ in the summer months. On the contrary, winter, which lasts from December to January, is extremely cold. Temperature falls to almost $5^{0} \mathrm{C}$ during the winter months in Delhi. The rainy season in Delhi begins in June and continues almost till October. Delhi receives most of its rain during this period from the Northwesterly winds. Most of the precipitation occurs in the month of July.

\section{METHODOLOGY AND DATA COLLECTION}

Detection of Urban growth and identification land use change in Delhi using Landsat satellite image. Used temperature mapping algorithm for detection urban growth and Land use \& land cover classification have been done using maximum likelihood classification technique. Different image processing \& enhancement technique used for identification the time-sequential changes in land use parents.

The data used for this dissertation consists of:

(1) Landsat7 MMS imagery, from band 1to band 4, on February, 1977.

(2) Landsat7 TM imagery, from band1 to band 7 on February, 1998, 2003.

(3) Landsat 8, 2014 imagery, from band1 to band 8 on February.

Here, Land sat TM, MSS, Landsat 8 images are used to fulfill this work and the using data was collected from USGS web site. For the extraction of Built-up land I used the MidIR, NIR band. Spatial resolution of NIR band of Landsat -TM \& Landsat -MSS is $120 \mathrm{~m}$ and $60 \mathrm{~m}$ respectively and spectral resolution of visible, infrared \& middle infrared region of Land sat-TM \&MSS is $30 \mathrm{~m} \& 60 \mathrm{~m}$. Due its moderate resolution spatial coverage, Land use \& land cover classification has been done for change detection analysis.

[n] Instruments Used: Garmin GPS 12: GPS was used to obtain the geographical co-ordinates of the observed filed location during the ground truth study for collecting Well distributed point, \& land use/land cover information.

Software's used: Image Processing: ERDAS Imagine 9.0 \& ENVI 5.0 Geographical Information System: Arc GIS 10.1 Others: MS-Office-2010(MS-word, MS-Excel) for documentation and calculation.

Table-1: Details of the satellite data used in this study.

\begin{tabular}{|c|c|c|c|}
\hline SL. No. & Data Use & Year & Source \\
\hline 1 & Landsat-7 TM & $1998,2003,2014$ & Glovis \\
\hline 2 & Landsat-7 MSS & 1977 & Glovis \\
\hline 3 & Google Earth Image & 2014 & Google Earth \\
\hline 4 & Hyperion EO-1 & 2003 & Glovis \\
\hline
\end{tabular}


A RS-GIS based Spatial Analysis and Assessment on the Urban Growth of Delhi National Capital ..

Table-2: Characteristics of the Landsat 7 TM, MSS and Landsat 8

\begin{tabular}{|c|c|c|c|c|}
\hline Sensors & Spectral bands & $\begin{array}{c}\text { Spatial } \\
\text { resolution }\end{array}$ & Spectral region & Time of acquisition \\
\hline \multirow{7}{*}{ Landsat-TM } & Band 1: $0.45-0.52 \mu \mathrm{m}$ & \multirow{5}{*}{$30 \mathrm{~m}$} & \multirow{4}{*}{ VNIR } & \multirow{7}{*}{ 1998,2003. February } \\
\hline & Band2: $0.53-0.60 \mu \mathrm{m}$ & & & \\
\hline & Band 3: $0.63-0.69 \mu \mathrm{m}$ & & & \\
\hline & Band 4: $0.75-0.90 \mu \mathrm{m}$ & & & \\
\hline & Band 5: $1.55-1.75 \mu \mathrm{m}$ & & SWIR & \\
\hline & Band 6: 1.04-12.5 $\mu \mathrm{m}$ & $120 \mathrm{~m}$ & TIR & \\
\hline & Band 7: 2.09-2.35 $\mu \mathrm{m}$ & $30 \mathrm{~m}$ & SWIR & \\
\hline \multirow{4}{*}{ Landsat-MSS } & 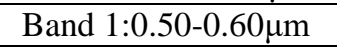 & \multirow{4}{*}{$60 \mathrm{~m}$} & Green & \multirow{4}{*}{ February 1977} \\
\hline & Band2:0.60-0.70 $\mu \mathrm{m}$ & & Red & \\
\hline & Band 3:0.70-0.80 $\mu \mathrm{m}$ & & \multirow{2}{*}{ Reflected IR } & \\
\hline & Band 4:0.80-1.11 $\mu \mathrm{m}$ & & & \\
\hline \multirow{8}{*}{ Landsat 8} & Band 1:0.45-0.52 $\mu \mathrm{m}$ & \multirow{6}{*}{$30 \mathrm{~m}$} & Visible & \multirow{8}{*}{ 2014,February } \\
\hline & Band 2:0.52-0.60 $\mu \mathrm{m}$ & & Visible & \\
\hline & Band 3:0.63-0.69 $\mu \mathrm{m}$ & & Visible & \\
\hline & Band 4:0.77-0.90 $\mu \mathrm{m}$ & & Near-Infrared & \\
\hline & Band 5:1.55-1.75 $\mu \mathrm{m}$ & & Near-Infrared & \\
\hline & Band 6:10.4-12.50 $\mu \mathrm{m}$ & & Thermal & \\
\hline & Band 7:2.09-2.35 $\mu \mathrm{m}$ & $60(30) \mathrm{m}$ & Mid-Infrared & \\
\hline & Band 8: 0.52-0.90 $\mu \mathrm{m}$ & $15 \mathrm{~m}$ & Panchromatic & \\
\hline
\end{tabular}

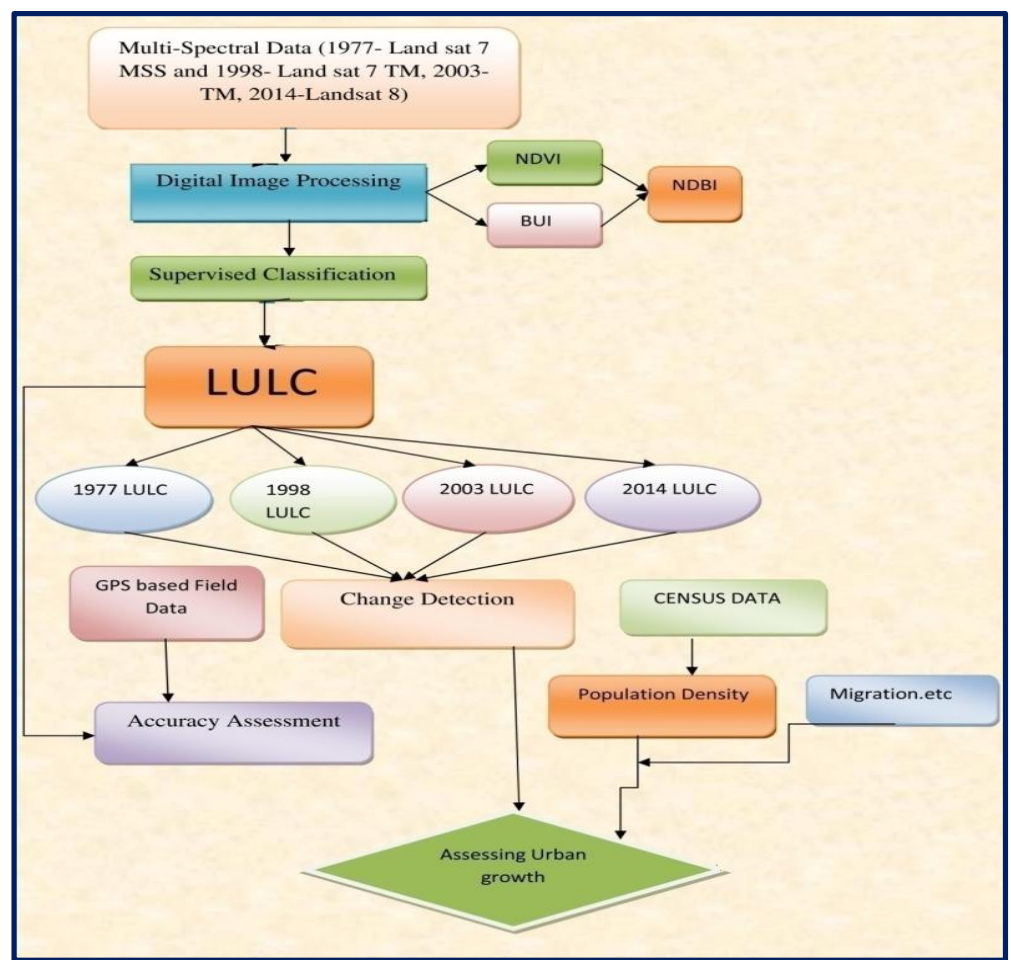

Figure 2: Methodological flow chart

\section{DATA ANALYSIS}

The primary source of the data used for the built-up land investigation on satellite image. The remotely sensed data used in this test is a Landsat 8, TM/ MSS image. The images are cloud-free and have excellent quality.

\section{@ Normalized Difference Vegetation Index (NDVI):}

Rouse et al. (1974) developed the generic Normalized Different Vegetation Index (NDVI). In the case of this study, NDVI has been used to validate one of the objectives.

$$
\text { NDVI }=\frac{\text { NIR - RED }}{\text { NIR + RED }}
$$


A Normalized Difference Vegetation Index (NDVI) is an equation that takes into account the amount of infrared reflected by plants. Live green plants absorb solar radiation, which they use as a source of energy in the process of photosynthesis. The reason NDVI is related to vegetation is that healthy vegetation reflects very well in the near-infrared part of the electromagnetic spectrum. Green leaves have a reflectance of $20 \%$ or less in the 0.5 to 0.7 micron range (green to red) and about $60 \%$ in the 0.7 to 1.3 micron range (near-infrared).

This spectral reflectance is themselves ratios of the reflected over the incoming radiation in each spectral band individually; hence, they take on values between 0.0 and 1.0.Shows the Normalized Difference Index (NDVI) drives from Land sat satellites image of the year of 2001 and 2011. In Figure: 3 and 4 NDVI values 0.0814 to 0.4375 represent the green coverage surface and Figure: 5 and 6 NDVI values 0.1559 to 0.4516 represent the green coverage surface.
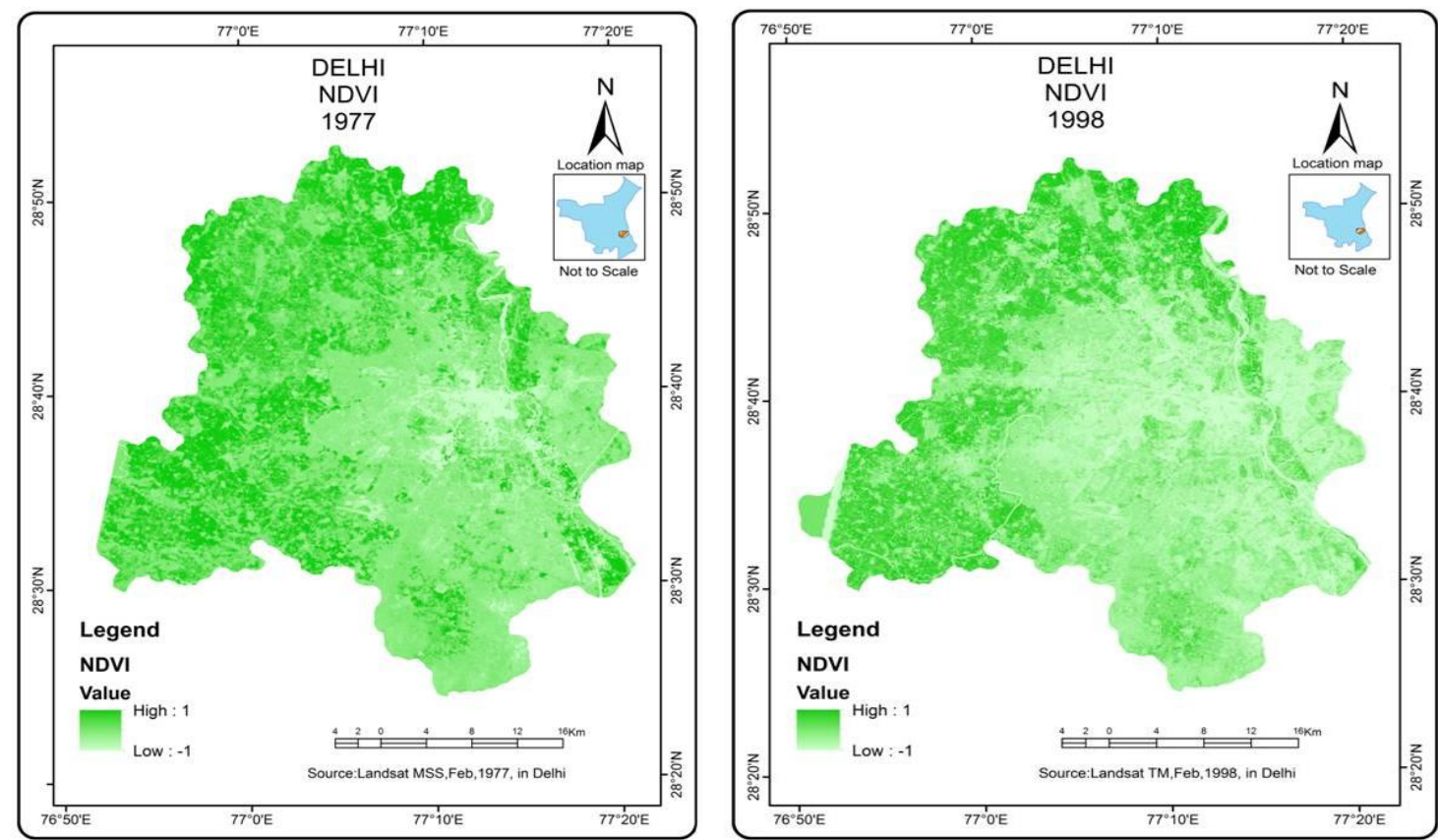

Figure 3 \& 4: NDVI in Delhi, 1977 \& 1998

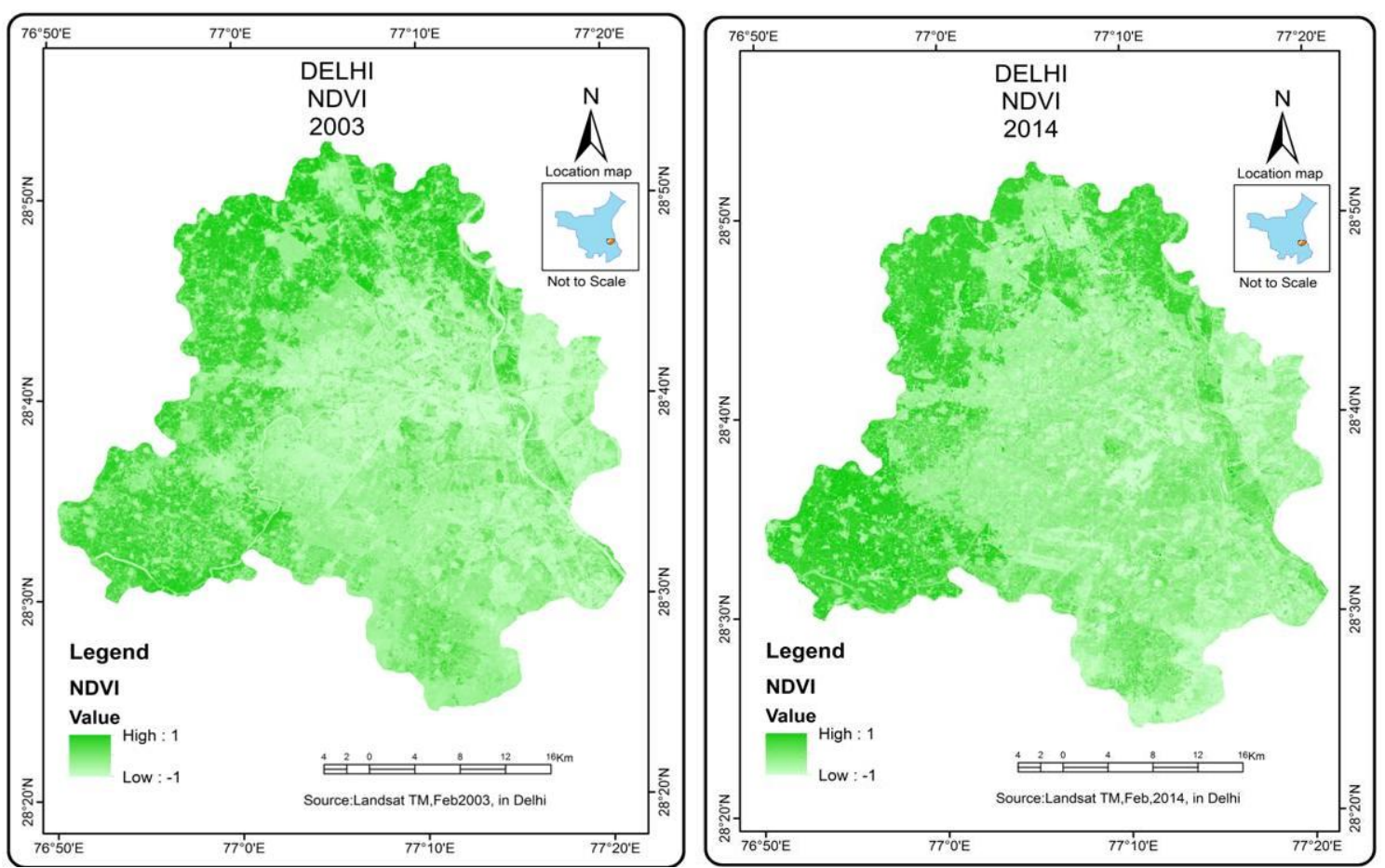

Figure 5 \& 6: NDVI in Delhi, 2003 \& 2014 
四 Normalized Difference Built-up Index (NDBI):

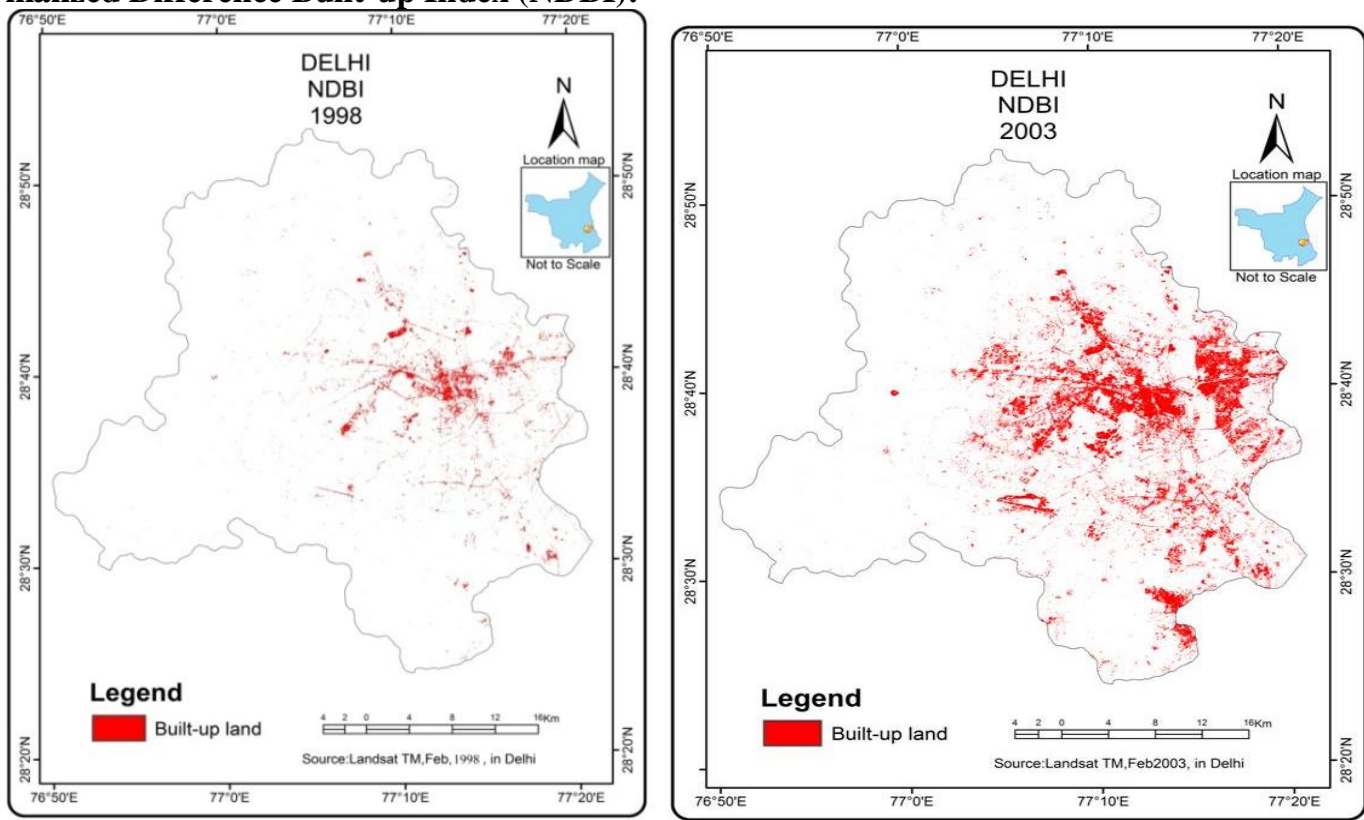

Figure-7 \& 8: NDBI in Delhi, 1998 \& 2003

These equation can be used for monitoring the built-up land Zha et al. (2003) calculated a normalized Difference Built-up Index (NDBI).

$$
\begin{aligned}
& \text { NDBI }=\text { Bui }- \text { NDVI } \\
& \text { Bui }=\frac{\text { MidIR }- \text { NIR }}{\text { MidIR }+ \text { NIR }}
\end{aligned}
$$

Where, this resulted in an output image that contained only built-up and barren pixels having positive values while all other land cover had a value of 0 or -254 . The technique was reported to be 92 percent accurate (J.R. Jensen et al., 2009).

The built-up areas of 2001 and 2011 were extracted from NDBI images. To extract the built-up area from the NDBI images we have to adopt the threshold technique, where a creating range of DN value is extracted from the index raster which may represent some typical kind of feature of interest. In general, we know that the positive values of NDBI are representing the built-up feature and negative values are representing the other land surface features.
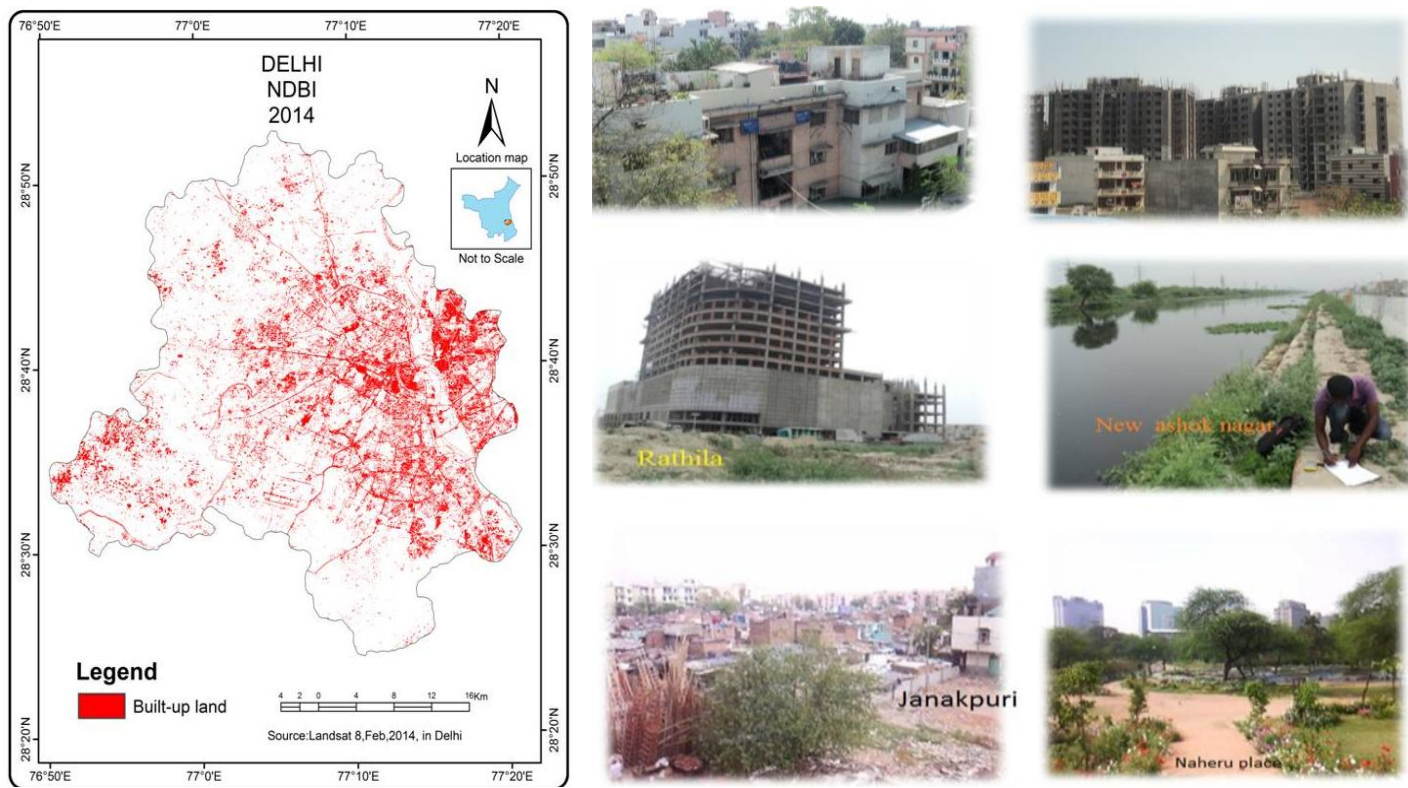

Figure-9: NDBI in Delhi, 2014 \& Photoplate -1: Field photo NCT of Delhi 


\section{Linmear Spectral Unmixing Techniques:}

Spectral unmixing of satellite images is one of the most widely used methods for deriving information from mixed pixels (Lu et al., 2003). The spectral unmixing method has been successfully used for assessing forest thinning (Lunette, 1998) and for forest land cover/land use change detection (e.g. Lu et al., 2003; Souza et al., 2003). The idea behind linear spectral mixture analysis is that every image pixel is a mixture of different components (called end members) and the spectrum recorded by the sensor is a linear combination of end member spectra (Tompkins et al., 1997). It has to be kept in mind that the assumption of linear mixing holds only if multiple scattering between different land cover types is insignificant (Tompkins et al., 1997; Wu \& Murray, 2003). Therefore, in the case of linear spectral mixing the value of a pixel in an image for a band equals the weighted sum of the radiance values for that band of all targets present in the pixel:

$$
n
$$

$$
\begin{array}{r}
\mathrm{Ri}=\sum \mathrm{f}_{\mathrm{k}} \mathrm{R}_{\mathrm{ik}}+\mathrm{ER}_{\mathrm{i}} \\
\mathrm{K}=1
\end{array}
$$

Where $i=1, \ldots, m$ (number of spectral bands); $k=1, \ldots, n$ (number of end members); $R i$ is the value of a pixel in band $i ; f_{k}$ is the fraction of end member $k$ in that pixel; $R_{i k}$ is the radiance of end member $k$ in band $i$; and $E R_{i}$ is the unmodelled residual in band $i$ (Weng et al., 2004).

Usually the end member fractions in a pixel are constrained to sum to unity and each end member fraction itself is expected not to have a negative value or be greater than 1 (Weng et al., 2004):

$$
\sum \mathrm{f}_{\mathrm{k}}=1 \text { and } 0 \leq \mathrm{f}_{\mathrm{k}} \leq 1
$$
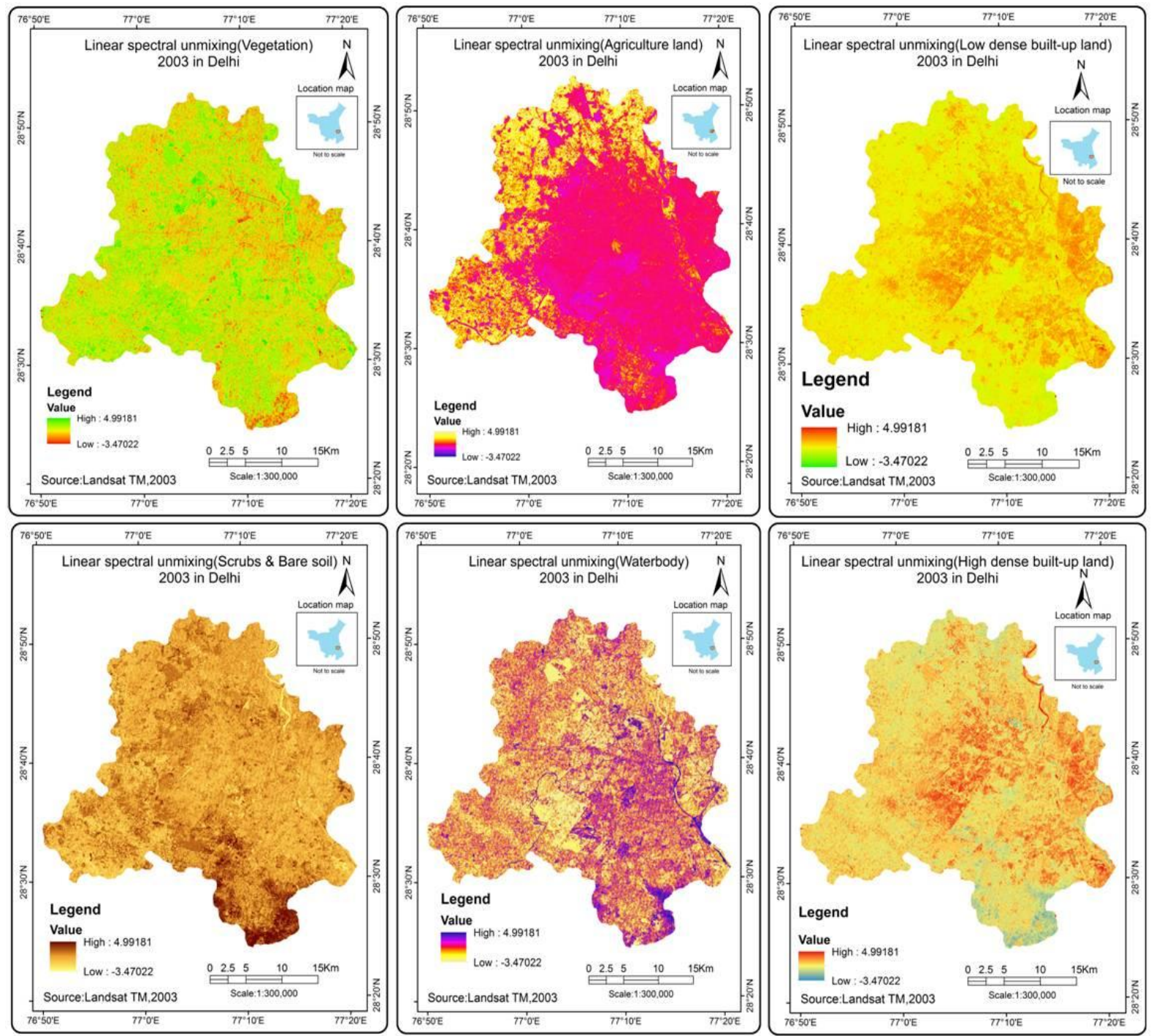

Figure 10: Linear spectral Unmixing map in Delhi, (Multi-spectral) 2014 

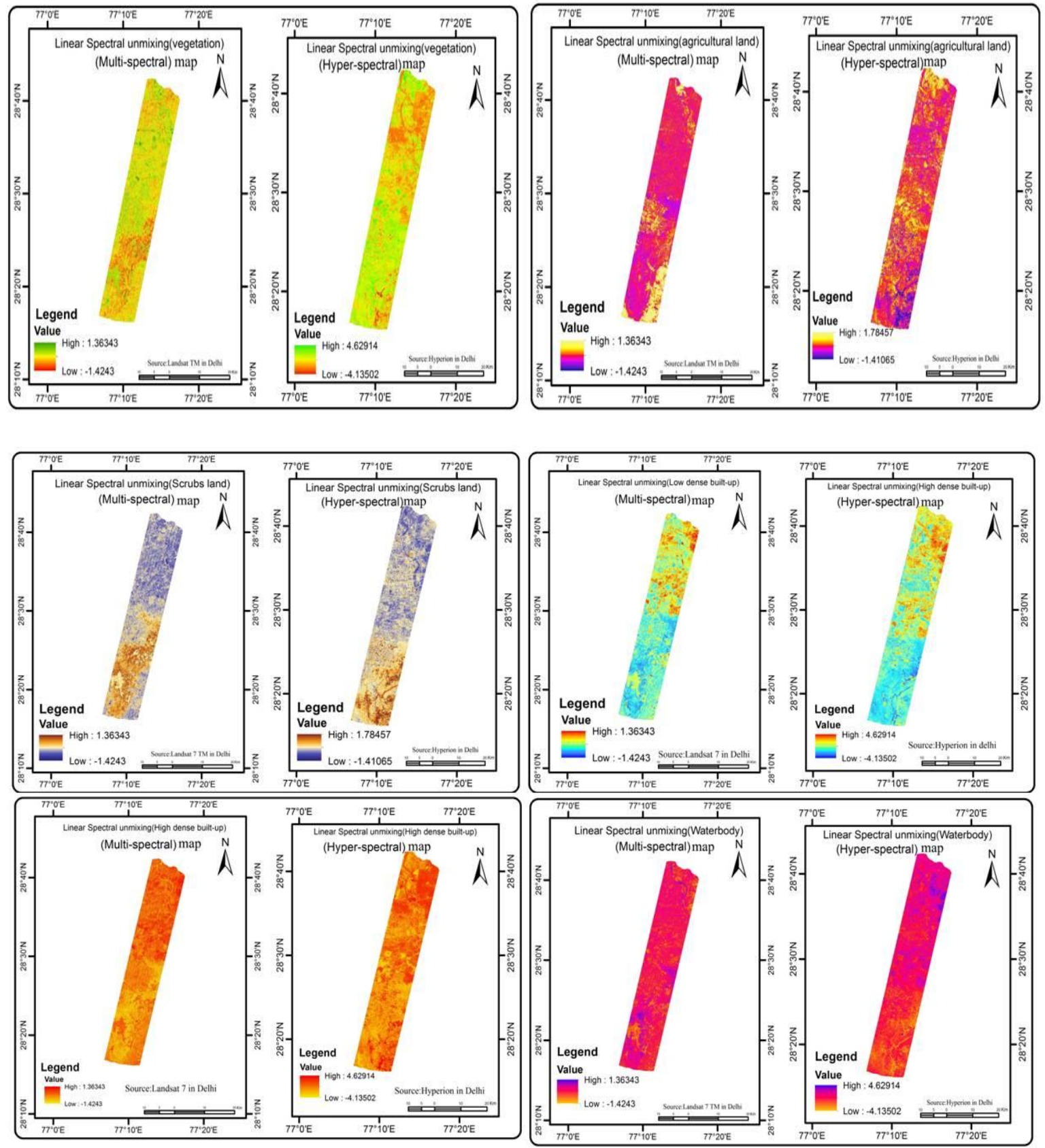

Figure 11 \& 12: Linear spectral Unmixing map in Delhi (Hypersexual)-2003

Figure: $10,11 \& 12$, represent the fractional images derived from linear spectral unmixing method for both multi-spectral and hyper-spectral imagery of 2003. The visual comparison between the fractional images of various land use land cover features shows similar spatial pattern.

\section{Land use \& Land cover:}

Land is one of the most important natural resource on which all human activities are based. Therefore, knowledge on different type of lands as well as its spatial distribution in the form of map and statistical data is vital for its geospatial planning and management for optimal use of the land resources. The information on land use/ cover inventory that includes type, spatial distribution, aerial extent, location, rate and pattern of change of each category is of paramount importance for assessing the impact of Urban growth on land use/ cover. The present framework of land use/cover classification has been primarily based on the "Manual of Nationwide Land Use/ Land Cover Mapping Using Satellite Imagery' developed by National Remote Sensing Agency, Hyderabad, Land use/vegetation cover map was prepared on the basis of image interpretation carried out based on the satellite data for the year 1977, 1998, 2003 \& 2014 through the help of Landsat-MMS, Land sat-TM \& landsat-8 satellite. 
A RS-GIS based Spatial Analysis and Assessment on the Urban Growth of Delhi National Capital ..
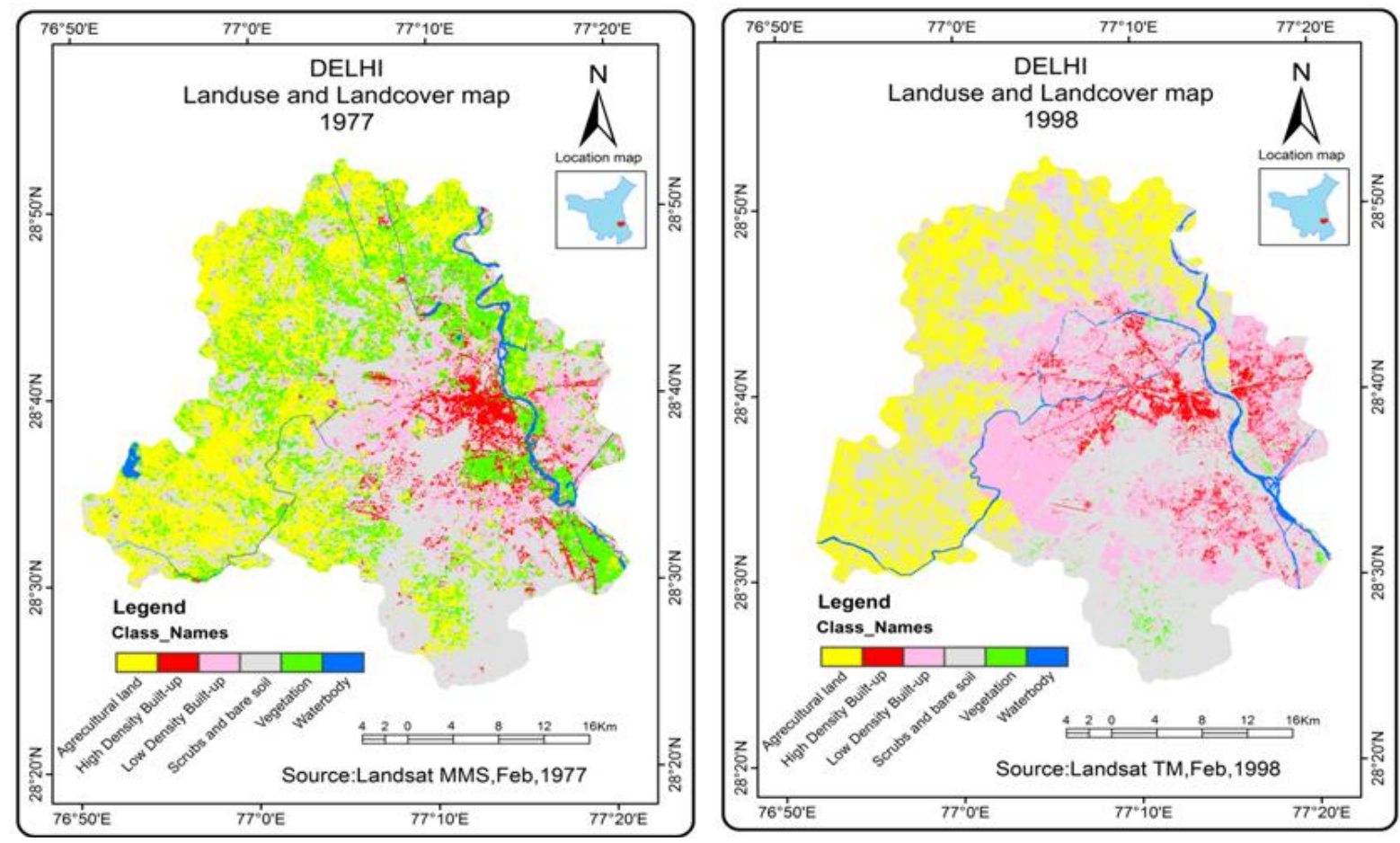

Figure-13 \& 14: Land use and Land cover Map of Delhi, 1977 \& 1998

\begin{tabular}{|c|c|c|c|c|}
\hline \multicolumn{5}{|c|}{ Table-3: LULC pattern NCT of Delhi \& surrounding 15m buffer Area (1977) } \\
\hline Class names & $\begin{array}{c}\text { Area sq.km(NCT } \\
\text { of Delhi) }\end{array}$ & $\begin{array}{c}\text { \% of Area (NCT } \\
\text { of Delhi) }\end{array}$ & $\begin{array}{c}\text { Area sq.km (15m } \\
\text { buffer area) }\end{array}$ & $\begin{array}{c}\text { \% of Area (15m } \\
\text { buffer area) }\end{array}$ \\
\hline Water body & 32.6655 & 1.70525158 & 43.0614 & 2.217898524 \\
\hline Scrubs and bare soil & 761.0364 & 51.67229976 & 634.2975 & 25.11847767 \\
\hline $\begin{array}{c}\text { Low Dense Built-up } \\
\text { land }\end{array}$ & 157.9698 & 10.72571937 & 196.7373 & 7.790889097 \\
\hline Agricultural land & 324.6939 & 22.04583188 & 863.2764 & 34.1861492 \\
\hline $\begin{array}{c}\text { High Dense Built-up } \\
\text { land }\end{array}$ & 165.5253 & 11.23871725 & 117.3348 & 4.646512959 \\
\hline Vegetation & 30.9222 & 26.55271949 & 670.5153 & 24.9471 \\
\hline Total & 1472.8131 & 100 & 2526.115 & 100 \\
\hline
\end{tabular}

\begin{tabular}{|c|c|c|c|c|}
\hline \multicolumn{5}{|c|}{ Table-4: LULC pattern NCT of Delhi \& surrounding 15m buffer Area (1998) } \\
\hline Class names & $\begin{array}{c}\text { Area sq.km(NCT } \\
\text { of Delhi) }\end{array}$ & $\begin{array}{c}\text { \% of Area (NCT } \\
\text { of Delhi) }\end{array}$ & $\begin{array}{c}\text { Area sq.km (15m } \\
\text { buffer area) }\end{array}$ & $\begin{array}{c}\text { \% of Area (15m } \\
\text { buffer area) }\end{array}$ \\
\hline Water body & 25.3377 & 1.719946751 & 26.4744 & 1.292186534 \\
\hline Scrubs and bare soil & 783.7596 & 33.98637844 & 853.8003 & 53.20233399 \\
\hline $\begin{array}{c}\text { Low Dense Built-up } \\
\text { land }\end{array}$ & 178.0877 & 12.08503266 & 129.7755 & 10.61018029 \\
\hline Agricultural land & 293.7834 & 19.9422917 & 1060.5699 & 34.12108871 \\
\hline $\begin{array}{c}\text { High Dense Built-up } \\
\text { land }\end{array}$ & 182.4638 & 12.38199484 & 6.1731 & 1.76515975 \\
\hline Vegetation & 10.1898 & 0.691693145 & 449.3223 & 18.22500626 \\
\hline Total & 1473.1677 & 100 & 2526.1155 & 100 \\
\hline
\end{tabular}

According to figure-10 \& figure-11, land use \& land cover map of Delhi for the year 1977 \& 1998, it is revealed that Agricultural land, Built-up land area these are major classes of this area. Vegetation found Central part, River side, north east portion of this area in1977, where vegetation found river side's, south portion in 1998. Scrubs and Bare soil found in western \& south portion of this area and Built-up land area extended from middle portion of the study area in the two years. Some agriculture land found in lower, basically both side of Yamuna River, Details land use/ land cover area and \% of each class present in table-. 3 \& 4 . 

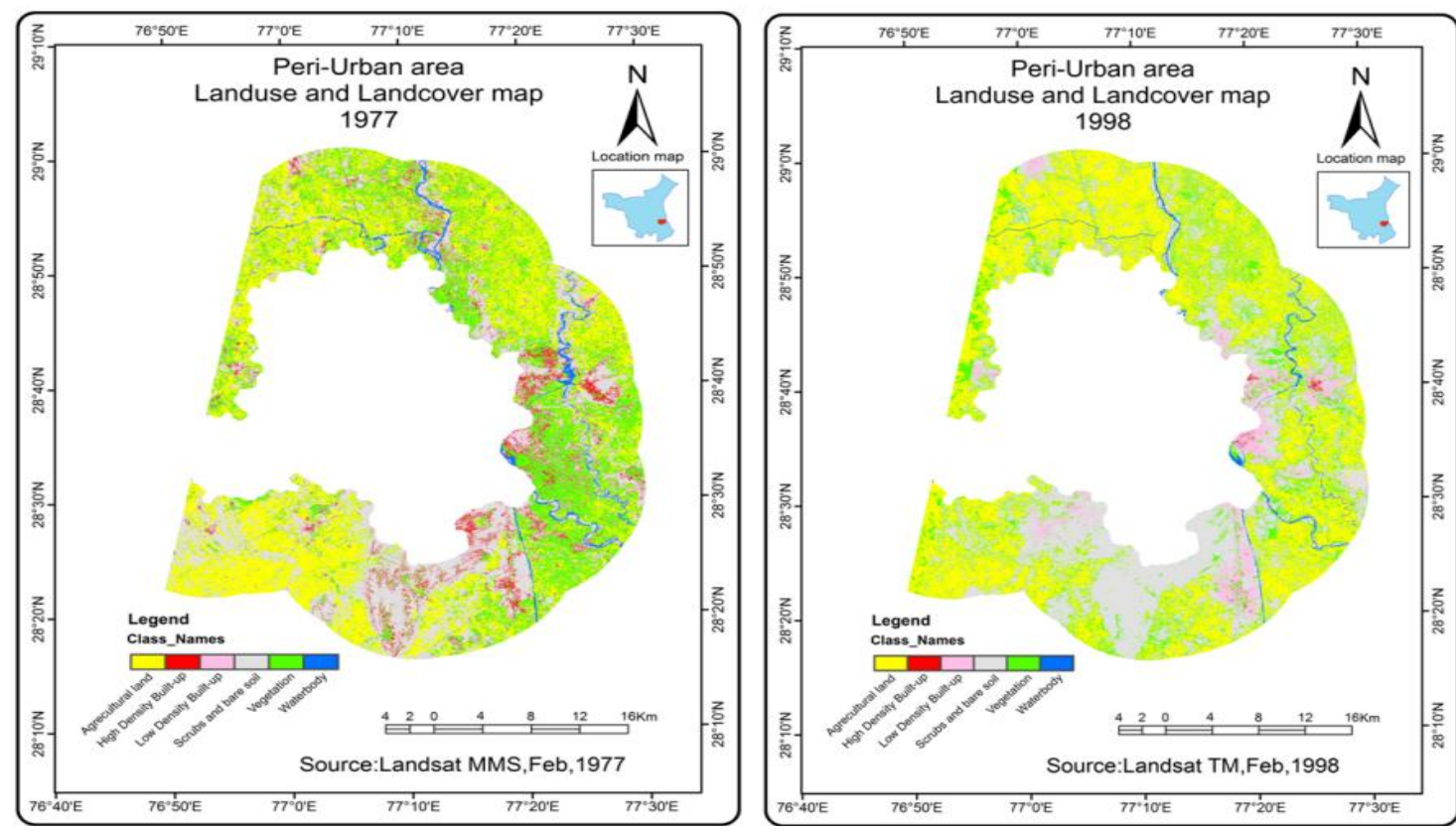

Figure-15: Land use Landcover pattern in peri-urban area, 1977, and 1998

NCT of Delhi surrounding area is called peri-urban area, in figure 11; represent two land use land cover maps in $1977 \& 1998$. Vegetation found the two peri-urban in riversides, north portion east portion. Scrubs land found south portion of this area in $1977 \& 1998$.
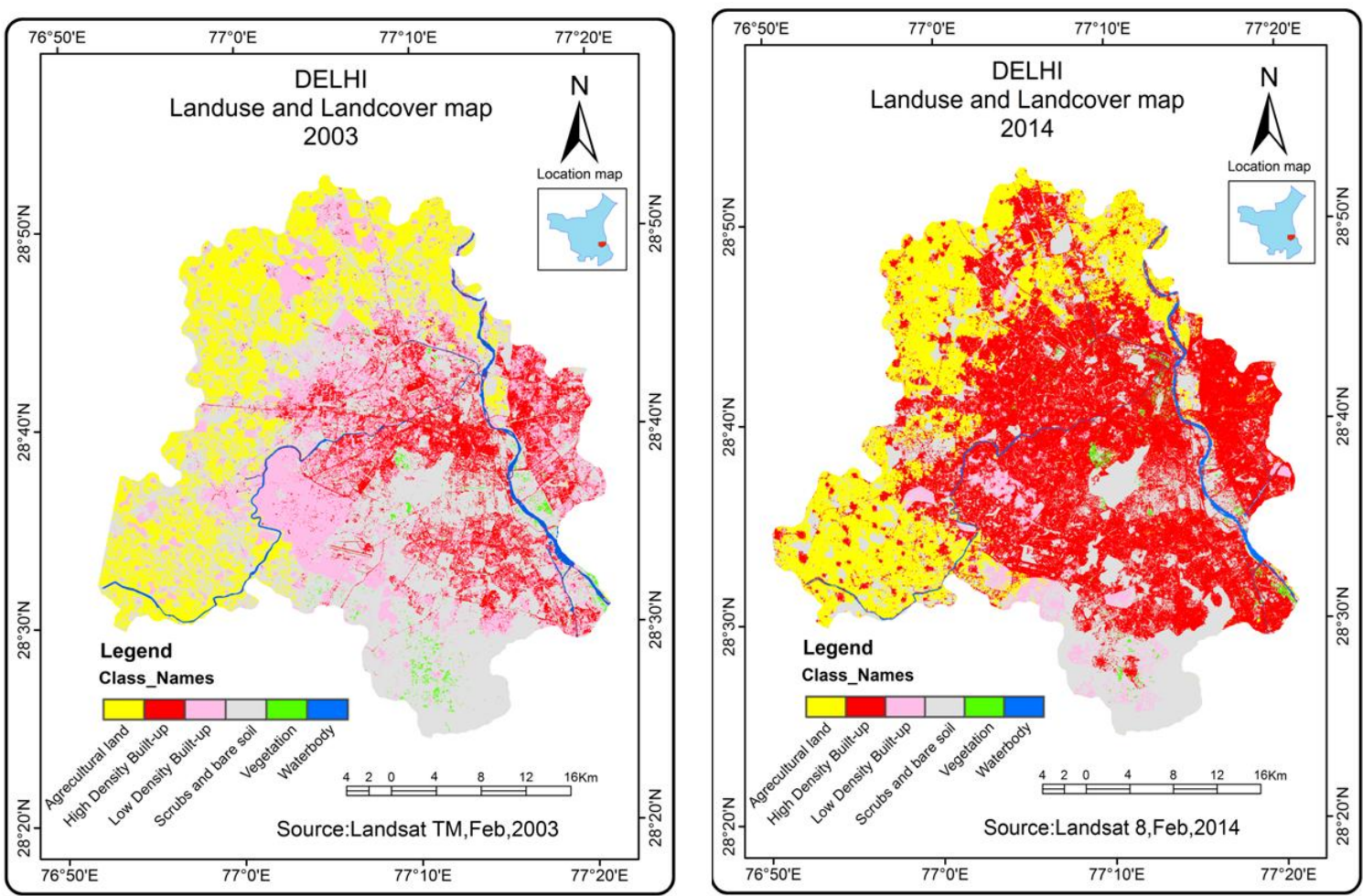

Figure-16 \& 16: Land use and Land cover Map of Delhi, 2003 \& 2014

According to land use/ land cover classification for the year 2003, 2014 and it is revealed that in Delhi mostly covered by Built-up land .Agriculture land found in north-western part. Scrubs land found are Southern part. Built-up area found in eastern \& middle part of this area. Yamuna is the one major river of this area, present in lower of Delhi. Some vegetation Land is mostly present in southern part, middle part and dense Built-up eastern part, middle portion of this area. Total area of land use/ land cover and \% of each class are present in table $3 \& 4$. 
A RS-GIS based Spatial Analysis and Assessment on the Urban Growth of Delhi National Capital ..

\begin{tabular}{|c|c|c|c|c|}
\hline \multicolumn{5}{|c|}{ Table-5: LULC pattern NCT of Delhi \& surrounding 15m buffer Area (2003) } \\
\hline Class names & $\begin{array}{c}\text { Area sq.km(NCT } \\
\text { of Delhi) }\end{array}$ & $\begin{array}{c}\text { \% of Area (NCT } \\
\text { of Delhi) }\end{array}$ & $\begin{array}{c}\text { Area sq.km (15m } \\
\text { buffer area) }\end{array}$ & $\begin{array}{c}\text { \% of Area (15m } \\
\text { buffer area) }\end{array}$ \\
\hline Water body & 19.4184 & 1.318139 & 14.6484 & 0.579878473 \\
\hline Scrubs and bare soil & 705.7818 & 47.90912 & 600.714 & 23.78014782 \\
\hline $\begin{array}{c}\text { Low Dense Built-up } \\
\text { land }\end{array}$ & 268.3953 & 18.21892 & 220.4442 & 8.726608106 \\
\hline Agricultural land & 265.626 & 18.02971 & 1082.042 & 42.83422908 \\
\hline $\begin{array}{c}\text { High Dense Built-up } \\
\text { land }\end{array}$ & 204.121 & 13.85498 & 51.7437 & 2.048350521 \\
\hline Vegetation & 9.9252 & 0.673731 & 556.5231 & 22.030786 \\
\hline Total & 1473.167 & 100 & 2526.115 & 100 \\
\hline
\end{tabular}

\begin{tabular}{|c|c|c|c|c|}
\hline \multicolumn{6}{|c|}{ Table-6: LULC pattern NCT of Delhi \& surrounding 15m buffer Area (2014) } \\
\hline Class names & $\begin{array}{c}\text { Area sq.km(NCT } \\
\text { of Delhi) }\end{array}$ & $\begin{array}{c}\text { \% of Area (NCT } \\
\text { of Delhi) }\end{array}$ & $\begin{array}{c}\text { Area sq.km (15m } \\
\text { buffer area) }\end{array}$ & $\begin{array}{c}\text { \% of Area (15m } \\
\text { buffer area) }\end{array}$ \\
\hline Water body & 17.3727 & 1.179277 & 15.6699 & 0.565959783 \\
\hline Scrubs and bare soil & 418.7628 & 28.42606611 & 661.0374 & 23.87510983 \\
\hline $\begin{array}{c}\text { Low Dense Built-up } \\
\text { land }\end{array}$ & 120.3767 & 8.171298961 & 15.0849 & 0.544830965 \\
\hline Agricultural land & 262.5652 & 17.8232062 & 1273.8582 & 46.00874993 \\
\hline $\begin{array}{c}\text { High Dense Built-up } \\
\text { land }\end{array}$ & 645.3799 & 43.80907689 & 731.8332 & 26.43208694 \\
\hline Vegetation & 8.7075 & 0.5910744 & 71.2467 & 2.573262553 \\
\hline Total & 1473.1677 & 100 & 2526.1155 & 100 \\
\hline
\end{tabular}
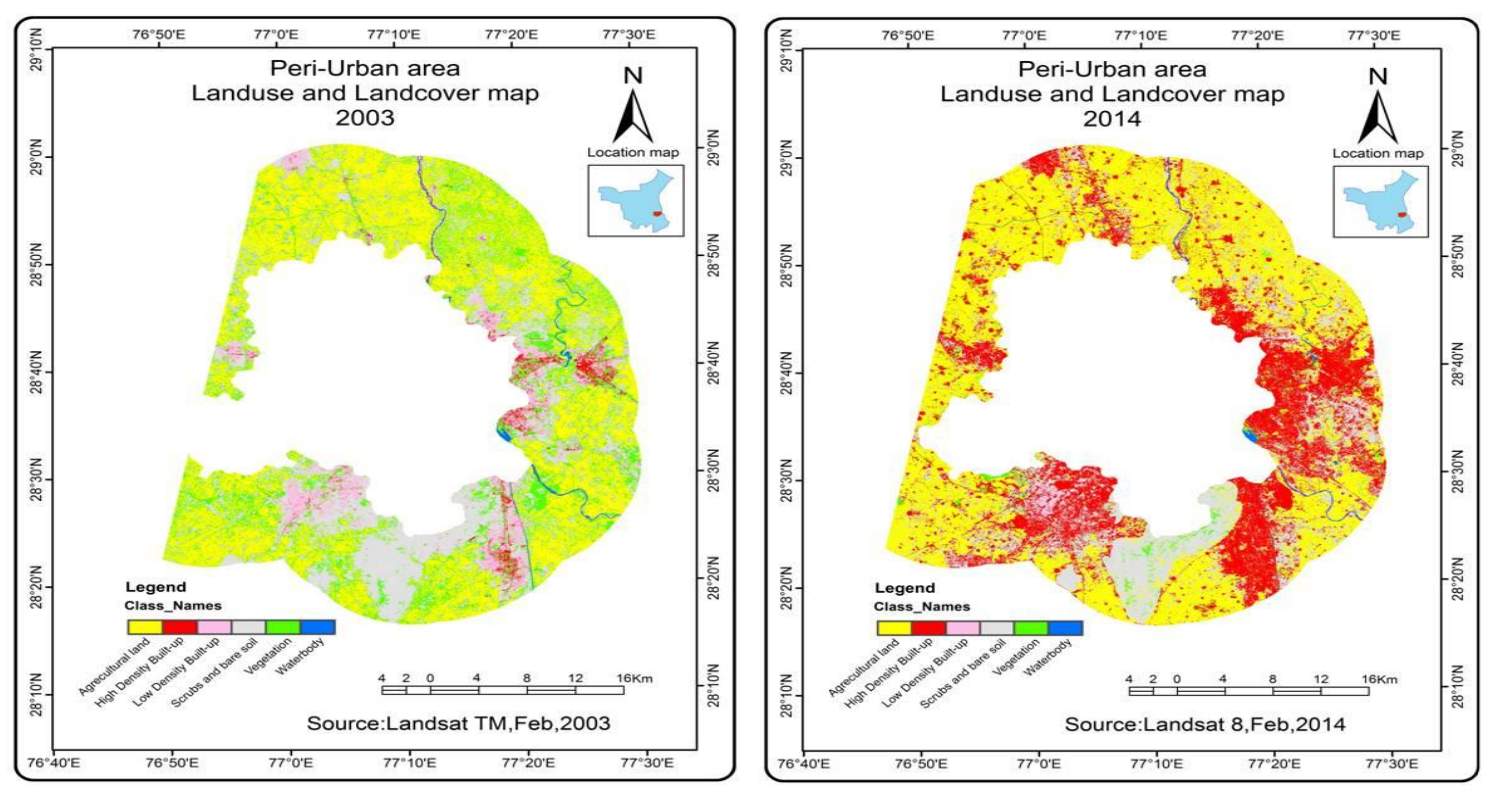

Figure-17: Land use Landcover pattern in peri-urban area, 2003 and 2014

Two peri-urban area in 2003 \& 2014 ,high dense built-up land found east portion in 2014, where some built-up land found east portion in 2003.Scrubs land to shows south portion in two years, but agricultural land north, north-south and some south-west portion of this area.

Figure-16 represents relationship between landuse landcover pattern peri-urban area and NCT of Delhi in 2003 \& 2014. In table-5 \& 6, Water body of peri-urban area was $2.21 \%$ where NCT of Delhi is $1.71 \%$.Low dense built-up and high dense built-up land was $10.61 \%$ and $1.76 \%$ in peri-urban area, where NCT of Delhi was $12.08 \%$ and $12.38 \%$ in 1977. Another 1998 we shows in table-4, waterbody and vegetation was $1.29 \%$ $\& 18.22 \%$ in peri-urban area, where water body and vegetation was $1.72 \% \& 0.69 \%$ in NCT of Delhi. But low and high dense built-up was $10.61 \% \& 1.76 \%$ in peri-urban area, where NCT of Delhi was $12.08 \% \& 12.31 \%$. 

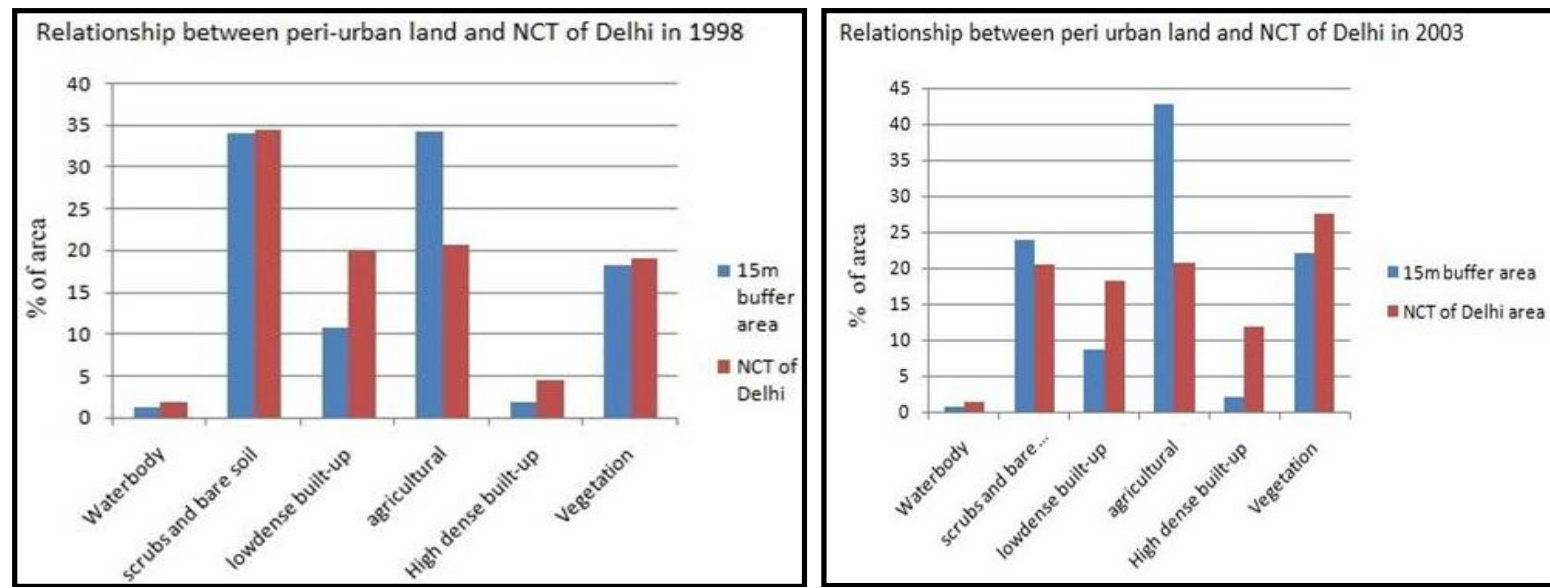

Figure-16 \& 17: Relationship between peri-urban land and Delhi NCT in 1998 and 2003

In table-5, Water body and vegetation of peri-urban area was $0.57 \% \& 22.03 \%$.where NCT of Delhi was $1.31 \%$ and $0.67 \%$ in 2003.Low dense built-up and high dense built-up land was $8.72 \%$ and $2.04 \%$ in periurban area, where NCT of Delhi was $18.21 \%$ and $13.85 \%$.Another 2014, we shows in table-6,waterbody and vegetation was $0.56 \% \& 2.57 \%$ in peri-urban area, where water body and vegetation was $1.17 \% \& 0.59 \%$ in NCT of Delhi. But low and high dense built-up was $0.54 \% 26.43 \%$ in peri-urban area, where NCT of Delhi was $8.1 \%$ $\& 43.50 \%$.
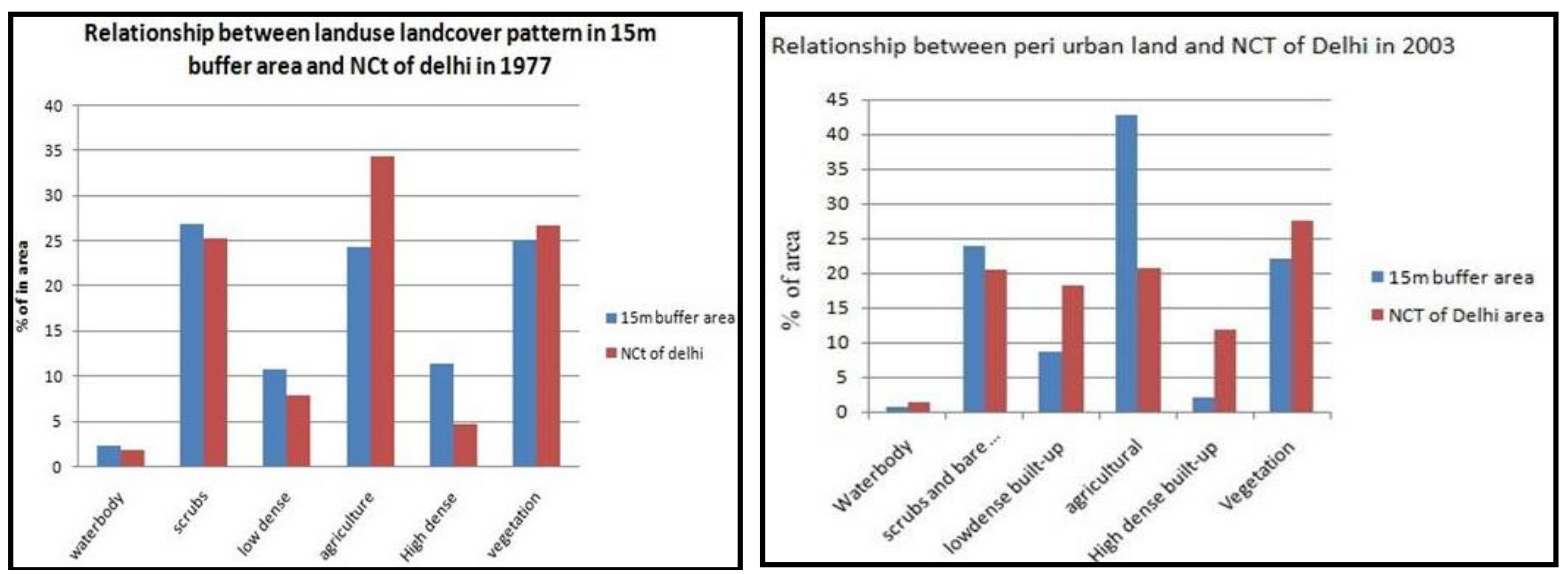

Figure-18 \& 19: Relationship between land use/ land cover of peri-urban land and Delhi NCT in 1977 and 2003
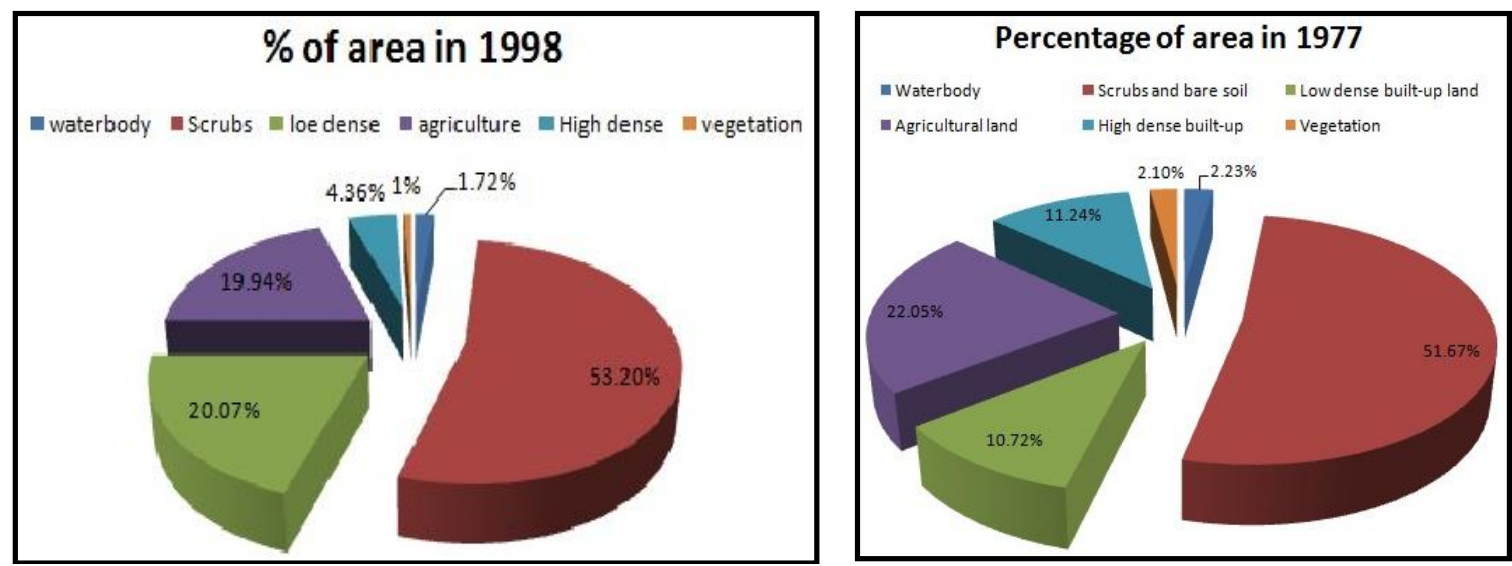

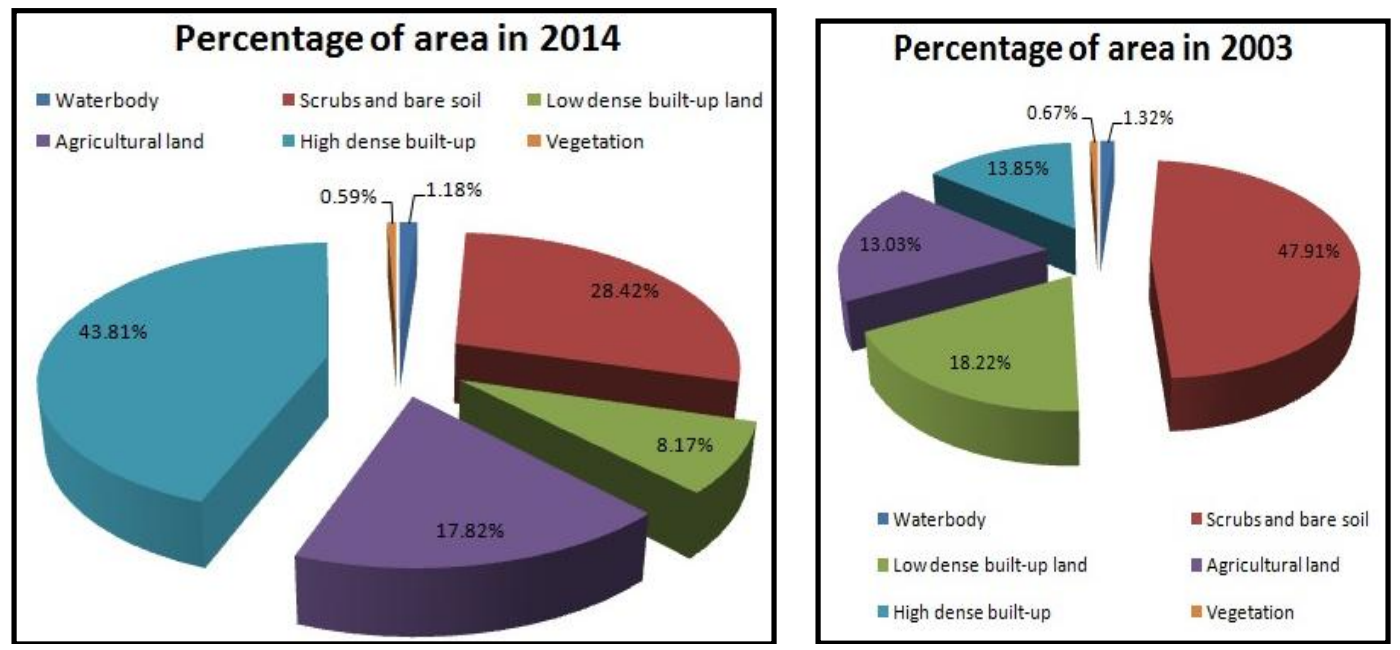

Figure-20, 21, 22 \& 23: Pie Diagram of various LULC Delhi (1977-2014)

\section{RESULT \& DISCUSSION:}

Built-up land has significantly impacted the forest cover, agriculture land, vegetation etc. In NCT of Delhi Analysis of the LULC maps (shown in Fig.) generated for the four time periods show changes in vegetation, scrubs and bare soil, agriculture land, Built-up land, water body etc.

Table-5 \& table-6 represents area occupied by the 6 LULC classes from 1977 to 2014. Significant changes in area of the vegetation, scrub and Bare soil, built-up land etc. was identified.Waterbody declined in area from 32.67 sq.km in 1977 to 25.34 sq.km in 1998 \& 19.42 sq.km in 2003, 17.37sq.km in 2014 respectively. While percentage of water body was $2.217898524 \%$ in 1977 to $1.719 \%$ in 1998 \& $1.32 \%$ in 2003 to $1.18 \%$ in 2014 of this area. Built-up area has significantly changes from 1977 to 1998 \& 2003 to 2014.High dense Builtup area was 204.121 sq.km and low dense built-up declined in area was 268.3953 sq.km in 1977 to high dense built-up was 182.4638 sq.km and low dense built-up was 178.0877 sq.km in 1998 \& 204.121 sq.km and 268.3953 sq.km in $2003,645.3799$ sq.km and 120.3767 sq.kim in 2014 respectively. While percentage area of high dense and low dense built-up is $11.24 \%$ and $10.73 \%$ in 1977 to $12.38 \%$ and $12.09 \%$ in $1998,13.85 \%$ and $18.21 \%$ in 2003 to $43.81 \%$ and $8.17 \%$ in 2014 of this area. Scrubs and Bare soil is $761.04 \mathrm{sq} \mathrm{km} \& 783.76 \mathrm{sq}$ $\mathrm{km}$ in 1977 and 1998, where percentage of scrubs land was 51.67\% and 53.19\% in 1977 and 1998.For Vegetation was $30.92 \mathrm{sq} \mathrm{km}$ and $10.19 \mathrm{sq} \mathrm{km}$ in $1977 \& 1998,9.93 \mathrm{sq} \mathrm{km}, 8.71 \mathrm{sq} \mathrm{km}$ in 2003 and 2014, percentage of vegetation was $2.10 \%$ and $0.69 \%$ in $1977,1998.2003$ and 2014 was $0.67 \%, 0.595 \%$.

\begin{tabular}{|c|c|c|c|}
\hline \multicolumn{4}{|c|}{ Table-7: Changing land use / land cover area in Delhi (1998 to 1977) } \\
\hline \multirow{2}{*}{ Class Name } & \multicolumn{2}{|c|}{ Area in \% } & \multirow{2}{*}{ Change of Area in \% } \\
\hline & 1977 & 1998 & \\
\hline Water body & 2.217898524 & 1.719416513 & -0.498482011 \\
\hline Scrubs and bare soil & 51.67229976 & $\mathbf{5 3 . 1 8 5 9 3 2 3 5}$ & 1.513632585 \\
\hline $\begin{array}{c}\text { Low Dense Built-up } \\
\text { land }\end{array}$ & 10.72571937 & 12.08503266 & 1.359313288 \\
\hline Agricultural land & 22.04583188 & 19.93614373 & -2.109688152 \\
\hline $\begin{array}{c}\text { High Dense Built-up } \\
\text { land }\end{array}$ & 11.23871725 & 12.38199484 & 1.143277585 \\
\hline Vegetation & 2.099533199 & 0.691479905 & -1.408053295 \\
\hline & 100 & 100 & \\
\hline
\end{tabular}

Table-7 represents rate of change in area of different LULC classes in 1998 to 1977. Different types of land use \& land cover present, but some classes increase and some classes reduce. Increase low dense built-up, high dense built-up and scrubs and bare soil of this area, but reduce water body, vegetation and agricultural land respectively. Low dense built-up, high dense built-up and scrubs land 1.14\%, 1.36\% and 1.51\%.reduse features' is $1.41 \%$ water bodies, $2.11 \%$ agricultural land and $0.50 \%$ Vegetation represent 1977 to 1998 . Heavy changes of total vegetated land indicate deforestation and natural degradation. Agriculture lands have reduced and scrubs land increase from 1977 to 1998 . Total agriculture land change. Due to reduce water body, which effects on agriculture land and reduce crop product. Finally reduce vegetation, increase low dense built-up land of 21 years periods and its related high dense built-up change of Delhi.. Details change of various land use \& land cover classes present in below figures-20 and 21 . 

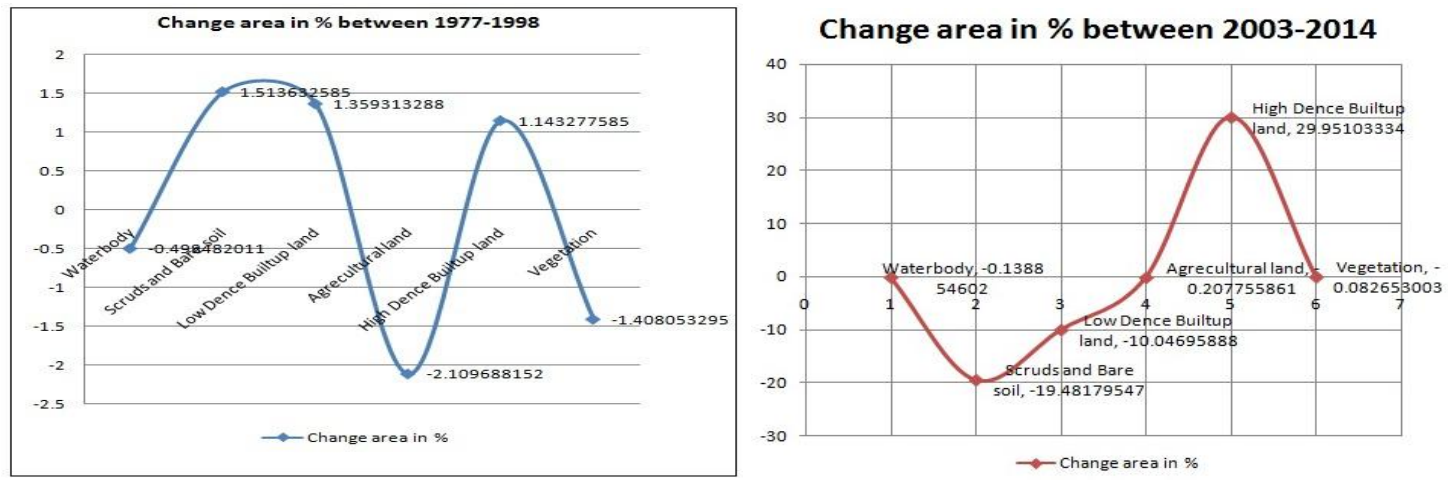

Figure-24 \& 25: Graphical representation of various LULC changes of Delhi (1977-1998 \& 2003-2014)

\begin{tabular}{|c|c|c|c|}
\hline \multicolumn{4}{|c|}{ Table-8: Changing land use / land cover area in Delhi (2003 to 2014) } \\
\hline \multirow{2}{*}{ Class Name } & 2003 & 2014 & \multirow{2}{*}{ Change of Area in \% } \\
\cline { 2 - 4 } Water body & 1.318049666 & 1.179195064 & $\mathbf{- 0 . 1 3 8 8 5 4 6 0 2}$ \\
\hline $\begin{array}{c}\text { Scrubs and bare soil } \\
\text { Low Dense Built-up } \\
\text { land }\end{array}$ & $\mathbf{4 7 . 9 0 5 8 7 6 1 7}$ & $\mathbf{2 8 . 4 2 4 0 8 0 7}$ & $\mathbf{- 1 9 . 4 8 1 7 9 5 4 7}$ \\
\hline $\begin{array}{c}\text { Agricultural land } \\
\text { High Dense Built-up } \\
\text { land }\end{array}$ & 18.21768712 & $\mathbf{8 . 1 7 0 7 2 8 2 3 9}$ & $\mathbf{- 1 0 . 0 4 6 9 5 8 8 8}$ \\
\hline Vegetation & $\mathbf{1 3 . 8 5 4 9 8 3 7 2}$ & $\mathbf{4 3 . 8 0 6 0 1 7 0 6}$ & $\mathbf{2 9 . 9 5 1 0 3 3 3 4}$ \\
\hline & $\mathbf{0 . 6 7 3 6 8 6 1 2}$ & $\mathbf{0 . 5 9 1 0 3 3 1 1 6}$ & $\mathbf{- 0 . 0 8 2 6 5 3 0 0 3}$ \\
\hline
\end{tabular}

Table-8, represents rate of change in area of different LULC classes in 2003 to 2014. Different types of land use \& land cover present, but some classes increase and some classes reduce. Increase high dense built-up of this area, but low dense built-up lands reduce respectively. Heavy changes of total vegetated land indicate deforestation and natural degradation. Agriculture lands and scrubs land reduces from 2003 to 2014. Total agriculture land change $0.21 \%$. Finally reduce vegetation $0.083 \%$. Total increase high dense built-up land $29.95 \%$ of 11 years periods and its related built-up land change of Delhi. Details change of various land use \& land cover classes present in figure-17 and figure-18.

\section{NCT OF DELHI: METRO-POPULATION DYNAMICS:}

The development of NCT Delhi and its metropolitan area characterizes major tendency in growing urbanization with an increasing concentration of urban population of ten million plus inhabitants. With regard to NCT Delhi, the demographic evolution is deeply marked by the country. In 1911, the capital was shifted to Delhi from Kolkata. Thereafter, the population of the city had increased from 413851 in 1911 to 1744072 in 1951.

\begin{tabular}{|c|c|c|c|c|c|c|}
\hline \multicolumn{7}{|c|}{ Table 9: Population, Area and Density of NCT Delhi (1901-2011) } \\
\hline Year & Population & $\begin{array}{c}\text { Growth Rate } \\
(\%)\end{array}$ & $\begin{array}{c}\text { Population } \\
\text { (Urban) }\end{array}$ & $\begin{array}{c}\text { Growth Rate } \\
(\boldsymbol{\%})\end{array}$ & $\begin{array}{c}\text { Area (Sq. } \\
\text { Km) }\end{array}$ & $\begin{array}{c}\text { Density (per Sq. } \\
\text { Km) }\end{array}$ \\
\hline 1901 & 405819 & - & 214115 & - & - & - \\
\hline 1911 & 413851 & 1.98 & 237944 & 11.13 & 43.25 & 5501 \\
\hline 1921 & 488452 & 18.03 & 304420 & 27.94 & 168.09 & 1811 \\
\hline 1931 & 636246 & 30.26 & 447442 & 46.98 & 169.44 & 2640 \\
\hline 1941 & 917939 & 44.27 & 695686 & 55.48 & 174.31 & 3991 \\
\hline 1951 & 1744072 & 90.00 & 1437134 & 106.58 & 201.36 & 7137 \\
\hline 1961 & 26586122 & 52.44 & 2359408 & 64.17 & 326.55 & 7225 \\
\hline 1971 & 4065698 & 52.93 & 3647023 & 54.57 & 446.26 & 8172 \\
\hline 1981 & 6220406 & 53.00 & 5768200 & 58.16 & 540.78 & 10666 \\
\hline 1991 & 9420644 & 51.45 & 8471625 & 46.87 & 624.28 & 13570 \\
\hline 2001 & 13850507 & 47.02 & 12905780 & 52.34 & 888.74 & 14521 \\
\hline 2011 & $1,67,53,235$ & & $1,63,33,916$ & & 1,483 & 11,297 \\
\hline
\end{tabular}


Delhi In 1901, the urban population of Delhi was 214115. In 1912, the capital was shifted from Calcutta to acquired land of 46 sq. kms south of the walled city called New. In 1951, the urban population more than doubled to 1.43 million from 0.70 million in 1941 due to forced migration after partition. In 1956, a contiguous landmass measuring $1483 \mathrm{sq}$. km was called the Union Territory of Delhi (UT). However, from 1992, it has been renamed as the National Capital Territory of Delhi (NCTD). As per the Regional Plan 2021, it has been indicated that the built up area of NCT Delhi has increased from 580.14 sq. km (1986) to $701.62 \mathrm{sq.km}$ (1999) which is more than $47 \%$ of the total area of NCT Delhi. As also observed from the above table, it can be stated that NCT Delhi has witnessed intense urbanization. The urban agglomeration area has increased from a mere $43.25 \mathrm{sq} \mathrm{km}$ in 1901 to $888.74 \mathrm{sq} \mathrm{km}$ in 2001 whereas during the same period density increased from 5501 persons per sq $\mathrm{km}$ to 14521 persons per sq $\mathrm{km}$. The spatial expanse of urban area and population growth has been concurrent in all the directions including sub-cities of Rhine, Dwarka, and Narela and also in TransYamuna Area. The total area of NCT Delhi is 147300 hectares (1473 sq. km) in 2014.

\begin{tabular}{|c|c|c|c|c|c|c|c|c|}
\hline \multicolumn{7}{|c|}{ Table 10: District wise population in NCTof Delhi, 1961-2011 } \\
\hline \multirow{2}{*}{ Districts } & \multicolumn{7}{|c|}{ Census Years } & $\begin{array}{c}\text { Population Density/ } \\
\text { Sq.km }\end{array}$ \\
\cline { 2 - 9 } & $\mathbf{1 9 6 1}$ & $\mathbf{2 0 0 1}$ & $\mathbf{2 0 1 1}$ & $\mathbf{1 9 9 1}$ & $\mathbf{2 0 0 1}$ & $\mathbf{2 0 1 1}$ & $\mathbf{2 0 0 1}$ & $\mathbf{2 0 1 1}$ \\
\hline $\begin{array}{c}\text { North } \\
\text { West }\end{array}$ & 240973 & 6502 & 8298 & 1777968 & 2860869 & 3651261 & 6502 & 8298 \\
\hline North & 611376 & 12405 & 14037 & 686654 & 781525 & 884318 & 12405 & 14037 \\
\hline North east & 38155 & 31019 & 39311 & 1085250 & 1768061 & 2240749 & 31019 & 39311 \\
\hline East & 135325 & 23606 & 27544 & 1023078 & 1463583 & 1707725 & 23606 & 27544 \\
\hline $\begin{array}{c}\text { New } \\
\text { Delhi }\end{array}$ & 143846 & 4841 & 3614 & 168669 & 179112 & 133713 & 4841 & 3614 \\
\hline Central & 672063 & 43092 & 38578 & 656533 & 646385 & 578671 & 43092 & 38578 \\
\hline West & 250702 & & 20416 & 1433038 & 2128908 & 2531583 & & 20416 \\
\hline $\begin{array}{c}\text { South } \\
\text { West }\end{array}$ & 251383 & 418 & 5458 & 1087573 & 175504 & 2292363 & 418 & 5458 \\
\hline South & 314789 & 589956 & 986856 & 1051881 & 2267023 & 2733752 & 986856 & South \\
\hline
\end{tabular}

The maximum decadal growth has taken place in south west district of about $30 \%$,the new stability of dwarka,which has came up in the ten years, is a major factor leading to high growth rate here. A lot of new settlements have also taken place in and around najafgarh, leading to population growth. The urbanized village such as kapashera, Bijwasam ctc have came heavily populated due to tenants who are migrants, mainly working in factories in gurgaon and in Delhi.North West and north east districts have both shown high growth. In North West district, which is largest district in Delhi both by area and by population? The slum rehabitation colons at narela bhalswa, sabda, ghevde, ctc have been selected in the decade while both north east and east district shave similar characterizes of providing affordable howsing. The population growth in east district is less compare to north east mainly because of the effect of removal of Yamuna and others long settled slum clusters which fell in east district, whereas an appreciable number of cluster still in north east district.

The nine districts vary greatly in population. The smallest population is of New Delhi district, which is mostly contiguous with the NDMC area and comprises mainly of offices and official residences belonging to the government of India embassies and commercial of Connaught place. The largest population is in North West district, which is also the largest in area and comprises of a vast area which was still fairly recently quite rural in character, but has now highly Urbanized and thickly populated. The pie chart above shows comparative population of the nine districts.

The figure-20 ,represent overall population density of Delhi has increased from 9340 persons per sq.km in 2001 to 11297 persons per sq.km in 2011.The variation of population density across the nine district as shown figure 21.The high density of population is north east and central part in NCT of Delhi in 2011, Which population density is 39311 persons per sq.km. Where 31019 persons per sq $\mathrm{km}$ in 2001.Low density is North west, new Delhi and south west portion of this area in 2011, where population density is below 8298 persons per sq.km. Where 2001 population density is below 6502 persons per sq $\mathrm{km}$.Others district population density is 8299 to 27544 persons per sq km in 2011, where 6503 to 23606 persons sq km in 2001. 


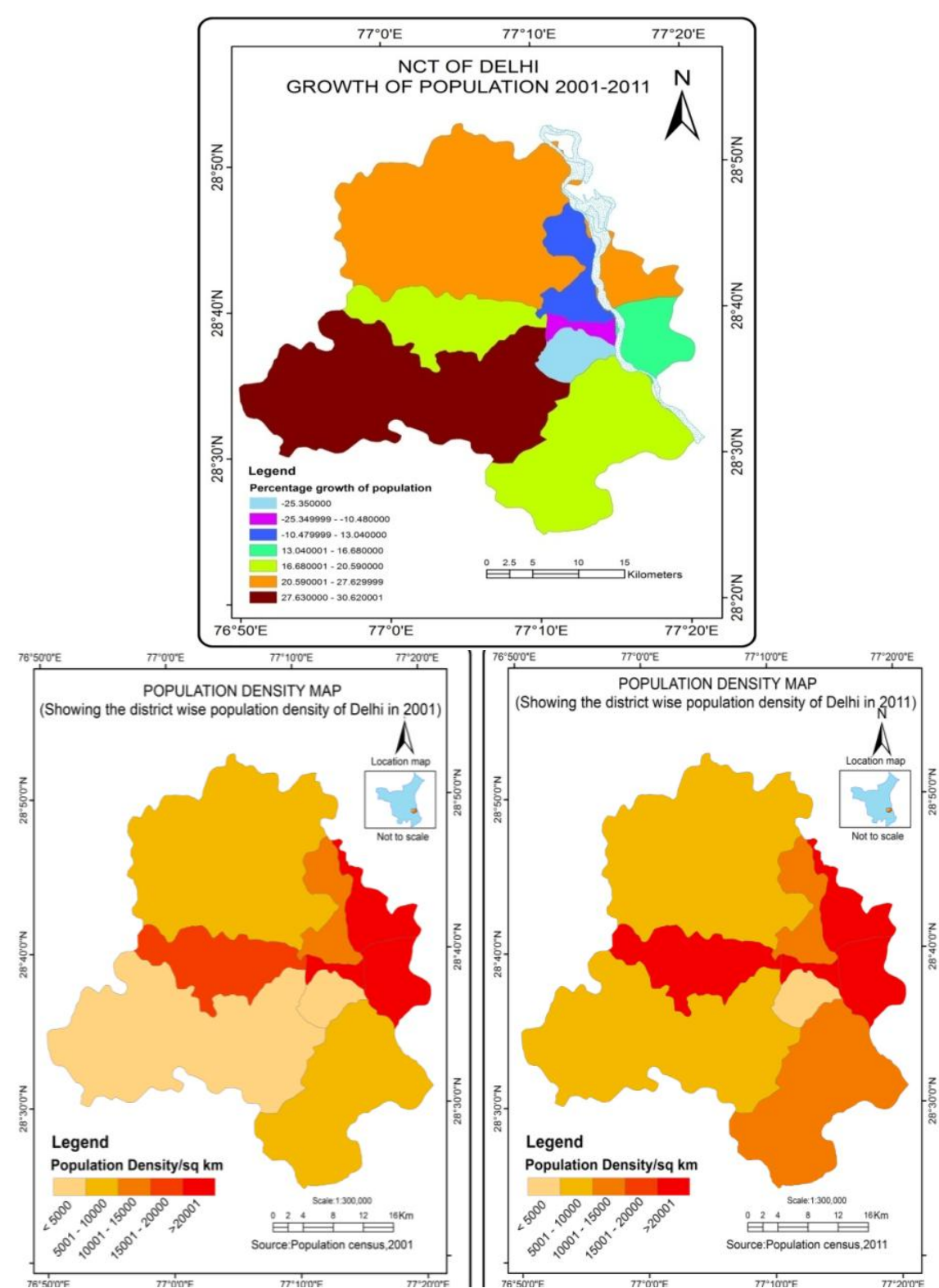

Figure-26: District wise population growth in Delhi 2001-2011 \& Figure -27: District wise population density in NCT of Delhi, 2001, 2011

\section{Migration to NCT Delhi:}

Migration has played a major role in the demographic evolution of NCT Delhi. Over one half of all migrants living in Delhi during 1991-2001 were from neighboring states in North India: Haryana, Punjab, Rajasthan and Uttar Pradesh. Delhi UA attracted very high number of migrants from other states in the last decade. The number of out migrants from Delhi was only 3.92 lakh. Thus the total number of net migrants was 1.6 million in 2001 in comparison to 1.3 million in 1991. Major influx of population into Delhi was from Uttar Pradesh (8.16 lakh), Bihar (3.82 lakh) and Haryana (1.5 lakh).Migrations from these states were male dominated.

As per 2001 Census, migration towards NCT Delhi has revealed interesting results. The adjoining states like Haryana, Uttar Pradesh and Rajasthan together still constitute maximum number of migrants moving towards NCT Delhi. These three states contributed 51.98\%, Uttar Pradesh (40.05\%), Haryana (7.87\%) and Rajasthan $(4.06 \%)$ respectively to the total migrants. 
A RS-GIS based Spatial Analysis and Assessment on the Urban Growth of Delhi National Capital ..

\begin{tabular}{|c|c|c|c|}
\hline \multicolumn{4}{|c|}{ Table-11: Migrants classified by place of last residence } \\
\hline \multirow{2}{*}{ Place of last Residence } & \multicolumn{3}{|c|}{ Migrants to Delhi (\%) } \\
\cline { 2 - 4 } & $1971-81$ & $1981-91$ & $1991-2001$ \\
\hline Uttar Pradesh & 50.09 & 48.5 & 40.05 \\
\hline Haryana & 12.93 & 11.51 & 7.87 \\
\hline Bihar & 5.77 & 10.69 & $\mathbf{5 . 1 1}$ \\
\hline Uttaranchal & - & - & 4.06 \\
\hline Rajasthan & 7.63 & 6.00 & 2.16 \\
\hline Punjab & 6.40 & 5.28 & $\mathbf{3 . 8 8}$ \\
\hline West Bengal & 2.70 & 2.72 & 1.82 \\
\hline Madhya Pradesh & 3.07 & 2.67 & 15.96 \\
\hline Others & 11.41 & \multicolumn{4}{|c|}{ Source: Migration Tables, Census of India, 2001 } \\
\hline \multicolumn{4}{|c}{}
\end{tabular}

As per Table-11, the migration from Uttar Pradesh including Uttaranchal has declined from 50.09\% in 1971-81 to $40.05 \%$ in 1991-01 excluding Uttaranchal. Similarly states of Haryana and Rajasthan have also shown declining trends. However, the migration from Bihar has increased by three times i.e. 5.77\% in 1971-81 to $19.09 \%$ in 1991-01. Hence, it can be seen that now migration from far off states have shown increasing trend in the last decade.

\begin{tabular}{|c|c|c|c|}
\hline \multirow{4}{*}{ Reasons } & \multicolumn{3}{|c|}{ Table 12: Reasons for migration } \\
\cline { 2 - 4 } & $1971-81$ & $1981-91$ & $1991-01$ \\
\hline Employment & 34.48 & 31.29 & 37.60 \\
\hline Business & - & 4.07 & 0.5 \\
\hline Education & 3.33 & 2.28 & 2.7 \\
\hline Family moved & 39.43 & 41.45 & 36.8 \\
\hline Marriage & 12.63 & 15.62 & 13.8 \\
\hline Natural Calamities & - & 0.13 & - \\
\hline Others & 10.14 & 5.16 & 6.3 \\
\hline Moved after Birth & - & - & 2.4 \\
\hline \multicolumn{4}{|c|}{ Source: Migration Tables, Census of India, 2001 } \\
\hline
\end{tabular}

As per the Table-12,it is clear that employment is still most important reasons for migration which constituted $37.6 \%$ of the various reasons stated by the migrants followed by movement of family (36.8\%) and marriage $(13.8 \%)$. Hence, NCT Delhi continues to be center of attraction wherein pull factors have been dominating as people by and large migrate for economic opportunities.

\begin{tabular}{|c|c|c|c|}
\hline \multicolumn{4}{|c|}{ Table-13: Variation in Migration of people to Delhi between 1991-2001 Based on migrants by last } \\
residence (0-9 years)
\end{tabular}

As observed from the above table, Delhi attracted large number of migrants from other states in the last decade. The total number of immigrants to Delhi during the last decade was 2.2 million while the numbers of out migrants from Delhi were 4.57 lakh and those who migrated from abroad were 49281 in the same period. Thus the total number of net - migrants was 1.7 million during 1991-2001 compared to 1.3 million during 198191. Thus the number of out-migrants has doubled during the same period. 


\section{IMPACT OF THE URBAN GROWTH IN AND AROUND THE DELHI NCT:}

The massive urban growth in and around the Delhi NCT region has serious impact upon natural environment and ecology which are summarized below---

\section{MEcological Effects of Urban Sprawl:}

Development plans that promote sprawl have a number of consequences for local ecosystems (Luther 2005). Many hold true for any development in the wild land-urban interface.

- Destruction of wildlife habitat.

- Introduction of non-native invasive plants and animals into natural areas.

- Increased human and pet exposure to diseases such as rabies and Lyme disease.

- Increased risks of water pollution from oil and gasoline washing off paved surface sand from pesticides, lawn fertilizers, and other chemicals.

- Increased potential for flooding and soil erosion due to impervious surfaces such as concrete or pavement.

- Decrease in groundwater for wells and irrigation caused by abundance of impervious surfaces.

- Increased risk to life and property from wildfires.

\section{Wocial and Economic Effects of Urban Sprawl:}

Urban sprawl can also negatively affect social and economic conditions in communities in several ways (Luther 2005).

- Increased community costs for maintaining roads, school bus routes, sewers, and other services needed when and residences are spread out.

- Ongoing increases in property taxes to meet growing need for services, which may pressure rural landowners to sell to developers.

- Increased need for automobiles; increased noise, traffic, pollution; reduced potential for bicycling and walking.

- Isolation of the young, poor, and elderly who cannot drive or lack access to cars.

- Increased cost and difficulty of providing public transportation.

- Increased time needed for transportation reduces time available to spend with family and friends or contributing to the com-munity.

- Loss of agricultural and forestry jobs, and traditional land practices.

- Reduction of rural character or community sense of place.

- Increased ordinances that regulate logging, noise, or odors.

\section{CONCLUSION}

The land-use/land-cover map prepared from Landsat-TM, MSS \& Landsat 8 data for identifying the time sequential change of LULC patterns. Built-up area has rapidly increased during 1977 - 2014; it is also noteworthy that the rate of urban growth was highest during 2003 to 2014 and a total increase of high density built-up land was found $47.01 \%$. It was happened mainly at the expense of agricultural land located at the outskirt of the city. After analyzing the change detection statistics, it was found that except high density built up land, the percentage of area under different land use land cover class i.e, water body, vegetation, agricultural land, has declined. The urban growth has occurred mainly in the south western part of Delhi, towards Dwarka. In order to identify the major causes of such a massive change in urban area, the population dynamics of the city was analyzed. The study shows that the overall population density of Delhi has increased from 9340 persons per sq.km in 2001 to 11297 persons per sq.km in 2011. The population dynamics of Delhi NCT is showing good agreement with the landuse dynamics as the highest population growth was found in the southwest Delhi. Also, the net influx of migrants has increased during the 2001-2011 decade and more than 35\% increase in net influx has recorded during the time period. It establishes the fact that there was an increasing demand for land to accommodate this large number of emigrants which has played as a fuelling factor for such an unprecedented growth.

This purpose of the study was to understand the spatio-temporal change in and around an urban landscape using RS \& GIS of the NCR region, Delhi. After the study, the results gave a deeper insight into the subject as well as the main objective i.e. the changing scenario over the NCR. Keeping in view this rapid conversion of natural landscapes to manmade landscapes in and around the NCR towns and also the rate of environmental degradation the region, the following four zones have been identified by NCRPB for application of strict land use control and development. The vulnerable areas have been grouped as follows:

(a) Urbanisable area,

(b) Green belt/green wedge is often converted to urban lands,

(c) Areas along the major transport routes,

(d) Remaining rural land is a common prey to urban land expansion due to its low cost. 
The governing bodies identify these regions and the likely major economic activities in thereof for proposing appropriate and viable land use conversions. With the policy of inducing development in the regional and sub-regional centers, the urbanization will be much more faster which implies additional land for urban expansion. In the same lines, land use policies are existing, designed by the NCRPB for regulating the density of settlements in the NCR:

(a) For urban centers upto1.0 lac population, a density of 80 persons per hectare,

(b) For urban centersof 1.0 lac of 5.0 lac population, a density of 110 persons per hectare, and

(c) For urban centers of more than 5.0 lac population, a density of 125 persons per hectare.

These policies along with the other quantified factors including spatial metrics should be used for designing the landscape with environmentalism as an important aspect in mind. Mitigating the UHI intensity wherein spatial metrics also has a role to play, increasing vegetation cover is the most widely applied measure which could achieve huge energy savings through temperature reduction of an area. But as mentioned above only the increase in quantity in few areas is not the solution but it has been uniformed and heterogeneous in its spread. It was reported in a study conducted by Spronken-Smith et al. (2000) that parks could help control temperatures through an evaporation of more than $300 \%$ as compared to its surrounding. Thus, areas in these cities where there is high contiguity of built up, there parks and gardens can be introduced. Some other traditional mitigation measures include lighter color of pavement and cooler roofs using spray; proper ventilation; shades; open and airy spaces; photovoltaic canopies (Golden et al., 2007) etc. Fortunately, urban heat island mitigation strategies - for example, trees and vegetation and green roofs - generally provide yearround benefits, or their winter penalty, such as that from cool roofs, is much smaller than their summertime benefits. Future policy efforts may focus on encouraging strategies to modify urban geometry and anthropogenic heat in communities to reduce urban heat islands. However, most effective mitigation measures for an area should be developed based on context/place specific spatio-temporal nature of UHI of an area. It is one future potential of this study where the mitigation strategies can be designed based on urban geometry.

It is critical that we develop an integrated approach at a time when urbanizing regions are facing rapid environmental change. Planners and managers worldwide face unprecedented challenges in accommodating urban populations and improving their wellbeing while simultaneously maintaining ecosystem functions. Agencies must devise policies to guide urban development and make decisions about investing in infrastructure that is both economically viable and ecologically sustainable. An integrated framework is required to assess the environmental implications of alternative urban development patterns and to develop policies to manage urban areas in the face of change. In particular, strategies for urban growth management will require such integrated knowledge to maintain ecological resilience by preventing development pressure on the urban fringe, reducing resource use and emissions of pollutants, as well as minimizing impacts on terrestrial ecosystems. The ecology of urban areas has long elicited the academic attention of ecologists, planners and social scientists and regional planners, there is much opportunity to extend and integrate knowledge of the metropolis using an ecological lens. How NCRPB and other planning and developmental authorities of the region manage urbanization and its ecology will be crucial to the health and wellbeing of billions of people in the region. It appears urgent to find solutions able to maintain the ecology and the biodiversity of conurbations with the sprawling urban areas, and contemporarily to assure a sustainable future to humanity.

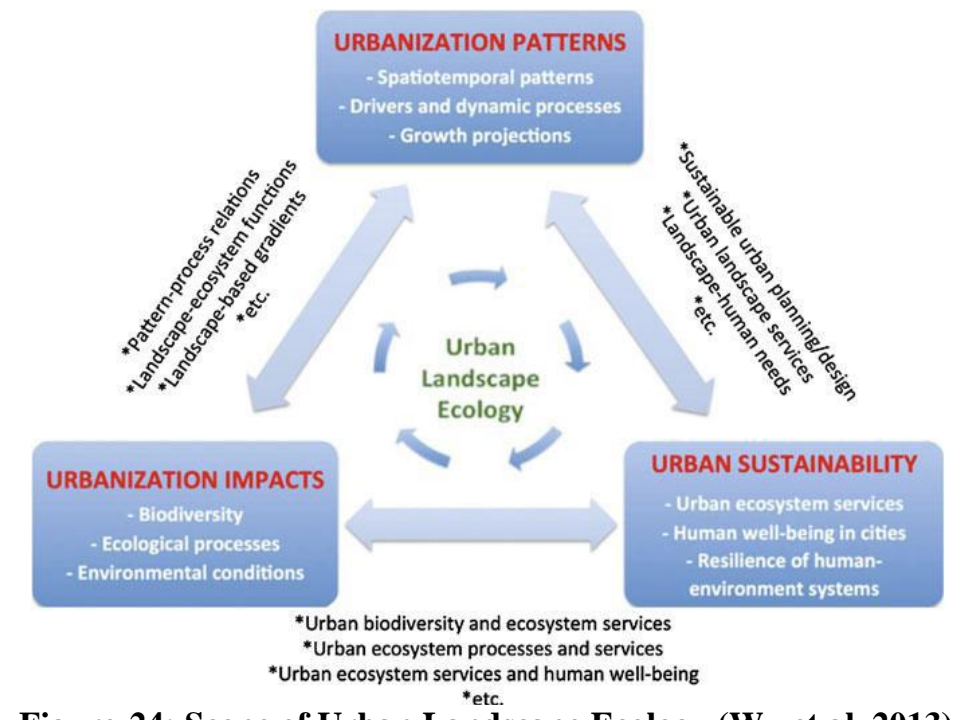

Figure-24: Scope of Urban Landscape Ecology (Wu et.al. 2013) 
"Landscape ecology needs to be more "urban;" urban ecology needs to be more landscape-realistic; both need to focus more on sustainability."-(Wu et.al. 2013)

\section{ACKNOWLEDGEMENT:}

We would like to express my sincere gratitude to the following persons without whom this case study would not have been carried out effectively and successfully.

We would specially consider the constant support and guidance from my supervisor Dr. Dipanwita Dutta, (Assistant Professor, Department of Remote Sensing \& GIS, Vidyasagar University, Paschim Medinipur-721102). Hereby we thank for her valuable and constructive suggestion during the planning and development of this work. Her willingness to give her time so generously has been very much appreciated. We wish to express my deep sense of gratitude to Mr. Sikhendra Kisor De, [Guest Lecturer, Vidyasagar University, Retired Director (Geophysics), Geological Survey of India and Faculty of Remote Sensing \& GIS Dept., Vidyasagar University] for his inspiring guidance and constant encouragement throughout this study work. We would also like to thank Dr. Abhisek Chakraborty (Assistant Professor, Department of Remote Sensing \& GIS., Vidyasagar University, Paschim Medinipur-721102), Dr. Jatisankar Bandyopadhyay (Professor, Department of Remote Sensing \& GIS., Vidyasagar University, Paschim Medinipur-721102) for their valuable thought and knowledge given throughout the study.

A special thanks needs to Glovis for providing us with the necessary satellite image, Census of India, 2001, Census Reports and District wise population in NCT of Delhi, 1961-2011 generate population Density, Migrants classified by place of last residence from Census of India, 2001, Reasons for migration from Census of India, 2001 and information regarding this work, for giving us necessary data relevant to our work. Finally, we would give our heartiest respects to Department of Environment and Forests, Government of NCT of Delhi, Delhi Development Authority-New Delhi and Ministry of Urban Development, Government of India, Town and Country Planning Organization, New Delhi for extending their broad minds and helping hands to complete this work.

\section{REFERENCE}

[1]. Allen and Lu, 2003; Han et al., 2009; Bhatta, 2010; Thapa and Murayama, 2011. Form Follows Function, Quantifying Urban Growth Pattern In Developing Countries Using Remote Sensing And Spatial Metrics.

[2]. (Lo, 2001; Lo and Yang, 2002; Weng, 2001;Cheng and Masser, 2003; Sudhira et al., 2004; Chabaeva et al., 2004; Jat et al., 2006).Statistical techniques along with remote sensing and GIS have been used in many urban sprawl studies.From fallows Urban growth and transport in Jeddah: Dynamic Modelling And Assessment.

[3]. Batty, M., and K.S. Kim, 1992. Form Follows Function: Reformulating Urban Population Density Functions, Urban Studies, 29:1043-1070.

[4]. Burchell, R. W.; and D. Listokin. 1995. Land, Infrastructure, Housing Costs and Fiscal Impacts Associated with Growth: The Literature on the Impacts of Sprawl vs. Managed Growth. Cambridge MA: Lincoln Institute of Land Policy.

[5]. Jensen, J.R., and D.C. Cowen, 1999. Remote Sensing of UrbanlSuburban Infrastructure and SocioEconomic Attributes, Photogrammetric Engineering 9 Remote Sensing, 65(5):611-622.

[6]. Luck \& $\mathrm{Wu}, 2002$, spatial metrics provides a linkage to structure, pattern, processes and functionality in urban studies, from fallows, Quantifying Urban Growth Pattern In Developing Countries Using Remote Sensing And Spatial Metrics.

[7]. Luther, T. 2005. "The Effects of Urban Sprawl on Forest Fragmentation and Parcelization." Private Forest, http://www.privateforest.org /forest101/sprawl.htm (accessed August 9, 2005).

[8]. Masek, J.G., F.E. Lindsay, and S.N. Goward, 2000. Dynamics of urban growth in the Washington DC metropolitan area, 1973-1996, from Landsat observations, International Journal of Remote Sensing, 21(18):3473-3486.

[9]. McFeeters, S.K., 1996. The use of normalized difference water index (NDWI) in the delineation of open water features, International Journal of Remote Sensing, 17(7):1425-1432.

[10]. Ottensmann, J.R., 1977. Urban Sprawl, Land Values and the Density of Development, Land Economics, 53(4):389-400.

[11]. Ray, T.W., 1994. Vegetation in remote sensing FAQs, Applications, ER Mapper, Ltd., Perth, unpaginated CD-ROM.

[12]. Ridd, M.K., 1995. Exploring a VIS (vegetation-impervious surface-soil) model for urban ecosystem analysis through remote sensing: Comparative anatomy for cities, International Journal of Remote Sensing, 16(12):2165-2185. 
[13]. Rossi, L., and Hari, R.E. (2007). Screening procedure to assess the impact of urban storm water temperature to populations of brown trout in receiving water. Integrated Environmental Assessment and Management, 3(3), 383-392.

[14]. Rouse, J.W., Hass, R.H., J.A. Schell and D.W. Deering, 1974, "Monitoring Vegetation System in the Great Plains with ERTS", Third Earth Resources Technology satellite-1 Symposium, Greenbelt: NASA SP-351, pp3010-3017.

[15]. Santamouris, M. (1995) The Athens urban climate experiment. In PLEA '98 1995 June 1998 (Lisbon). James \& James Science Publishers Ltd 1998:147-52

[16]. Scholz, M., and Grabowiecki, P. (2007). Review of permeable pavement systems. Building and Environment, 42(1), 3830-3836.

[17]. Y. Zha, J. Gao and S. Ni (2003), Use of normalized difference built-up index in automatically mapping urban areas from TM imagery, International Journal of Remote Sensing 24 (3) (2003), pp. 583-659. 